\title{
Oxysterols: A World To Explore
}

Author: Otaegui-Arrazola, A., Menéndez-Carreño, M., Ansorena, D., Astiasarán, I.

Institution: Department of Food Science and Nutrition, Physiology and Toxicology, Faculty of Pharmacy, University of Navarra, Irunlarrea sn, 31008, Pamplona, Spain

Corresponding author: Diana Ansorena Artieda; Department of Food Science and Nutrition, Physiology and Toxicology, Faculty of Pharmacy, University of Navarra, Irunlarrea sn, 31008, Pamplona, Spain. 0034948425600 (Ext 6263). Fax: 0034948 425649. dansorena@unav.es

Running title: Oxysterols: A world to explore

Keywords: COPs, POPs, oxidation, cholesterol, phytosterols, oxysterols.

\section{Abbreviations}

ABC: ATP Binding Cassete; ACAT: Acyl-coA Cholesterol Acyl Transferase; BHT: Butylated hydroxyl toluene; COP: Cholesterol Oxidation Product; EC: Epoxycholesterol; EPIC: European Prospective Investigation into Cancer; ER: Endoplasmic Reticulum; HC: Hydroxycholesterol; HDL: High Density Lipoprotein; HMC-CoA: 3-hydroxy-3-methil-glutaryl-CoA; ICAM: Intercellular Adhesion Molecule; IL: Interleukin; Insig: Insulin Induced Gene); KC: Ketocholesterol; LCAT: Lecitin Cholesterol Acyl Transferase; LDL: Low Density Lipoprotein; LXR: Liver X Receptor; MCP: Monocyte Chemotactic Protein; MIP: Macrophage Inflammatory Protein; POP: Phytosterol Oxidation Products; SCAP: SREBP-Cleaveage Activating Protein; SREBP: Sterol Regulatory Element Binding Protein; VCAM: Vascular Cell Adhesion Molecule; VLDL: Very Low Density Lipoprotein. 


\section{Abstract}

Oxysterols (oxidized derivatives of cholesterol an phytosterols) can be generated in the human organism through different oxidation processes, some requiring enzymes. Furthermore, oxysterols are also present in food due to lipid oxidation reactions caused by heating treatments, contact with oxygen, exposure to sunlight, etc., and they could be absorbed from the diet, at different rates depending on their side chain lenght.

In the organism, oxysterols can follow different routes: secreted into the intestinal lumen, esterified and distributed by lipoproteins to different tissues or degraded, maily in the liver. Cholesterol oxidation products (COPs) have shown citotoxicity, apoptotic and pro-inflammatory effects and they have also been linked with chronic diseases including atherosclerotic and neurodegenerative processess. In the case of phytosterols oxidation products (POPs), the evidences for toxic effects need more research. Nevertheless, current knowledge suggest their relation to cytotoxic and proapoptotic effects, although at higher concentrations than COPs.

Recently, new beneficial biological activities of oxysterols are being under research. Whereas COPs are associated with cholesterol homeostasis mediated by different mechanisms, the implication of POPs is not clear yet.

Available literature on sources of oxysterols in the organism, metabolism, toxicity and potential benefitial effects of these compounds are reviewed in this paper. 


\section{Introduction}

Oxysterols are oxidized derivatives of cholesterol and phytosterols, which are the main animal and plant sterols, respectively. Cholesterol is widely known for its association with atherosclerosis disease, while phytosterols have been proven to reduce serum cholesterol levels, decreasing the risk of cardiovascular diseases (Peterson, 1951; Vanhanen, et al. 1993; Miettinen, et al. 1995; Pelletier, et al. 1995). Nevertheless, cholesterol is a necessary constituent in the human organism, fulfilling important functions: maintenance of cell membranes, generation of steroid hormones, bile acids production...(Simons and Ikonen, 2000). Hence, cholesterol can be endogenously produced. On the other hand, phytosterols must be acquired from the diet; oils, spreads, nuts and seeds are all rich in phytosterols. Among these compounds, the most abundant are sitosterol and campesterol; stigmasterol and brassicasterol however, are less common. Amounts between 2-3g/day have been demonstrated to reduce serum LDL-cholesterol levels in humans by $10 \%$ (Katan et al., 2003; Berger et al., 2004). These doses are higher than the usual dietary intake, and nowadays, phytosterol-enriched foods are commercially available.

The structures of cholesterol and phytosterols are very similar (Fig. 1); they both have a steroid nucleus and a hydroxyl group in C-3. Due to the presence of a double bond between $\mathrm{C} 5-\mathrm{C} 6$, sterols can undergo oxidative processes (Hovenkamp et al., 2008). In contrast, plant stanols do not have this double bond and are unlikely to oxidize (Soupas et al., 2004). The difference between cholesterol and phytosterols resides in the side chain, located in C-17. Compared to cholesterol, phytosterols have different substitutions in C-24 (Hovenkamp et al., 2008).

$<$ Insert Figure 1>

The oxidation of the C5-C6 double bond, or of those in other positions in the steroid ring or side chain of sterols, results in the formation of oxysterols or sterol oxidation products (SOPs). In the case of cholesterol oxidation, the resulting products 
are usually named COPs (cholesterol oxidation products) and when phytosterols are oxidized, the resulting products are named POPs (phytosterol oxidation products).

COPs have been studied and identified since 1966 when they were first detected in human atheromatous plaques (Brooks et al., 1966). In the 90s, the isotope dilution mass spectrometry enabled the study of COPs in human plasma (Breuer and Björkhem, 1990; Dzeletovic et al., 1995). Since then, 7a-hydroxycholesterol (7a-HC),

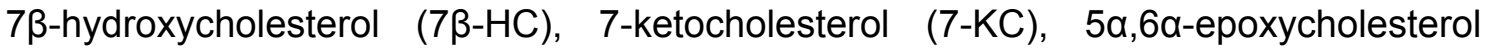

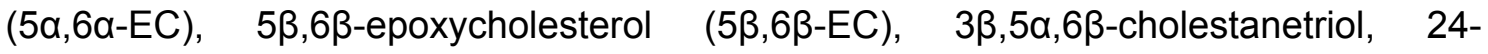
hydroxycholesterol (24-HC), 25-hydroxycholesterol (25-HC) and 27-hydroxycholesterol (27-HC) have been found in human biological samples.

On the other hand, POPs were not discovered until 1983, when $\alpha$ and $\beta$ epoxydes of sitosterol were quantified in the plasma of a patient with Waldenström's macroglobulinaemia (Brooks et al., 1983). Later, other oxysterols, mainly epoxysitosterols, were identified in phytosterolemic patients, but not in healthy volunteers (Plat et al., 2001). Nevertheless, recently, several POPs have been found in plasma of healthy subjects (Grandgirard et al., 2004a). $\beta$-epoxysitostanol and sitostanetriol were the most abundant, while campestanetriol, a-epoxysitostanol, 7ketositosterol and 7ß-hydroxysitosterol concentrations were lower. Menéndez-Carreño et al. (2008a) found $7 \alpha$-hydroxysitosterol $(47.3 \mathrm{ng} / \mathrm{mL})$ and $7 \beta$-hydroxysitosterol (49.0 $\mathrm{ng} / \mathrm{mL}$ ) in the serum of healthy volunteers.

COPs are now thought to be potentially involved in the initiation and progression of major chronic diseases including atherosclerosis, neurodegenerative processes, diabetes, kidney failure, and ethanol intoxication (Guardiola et al., 1996, 2002; Sottero et al., 2009), while POPs have been proven to be associated with atherosclerosis and cytotoxic effects, although at high doses (Meyer et al., 1998; Maguire et al., 2003). For these reasons, this present review intents to clarify the different oxysterol sources, their biological effects and their potential toxicity. 


\section{Sources of oxysterols}

There are three trains of thought that could explain the presence of oxysterols in human plasma; 1) In vivo transformation of cholesterol and phytosterols in cells, blood and tissues to form oxysterols. This endogenous source does not appear to explain the presence of all the COPs and POPs in human plasma and tissues. 2) In vivo oxidation of cosmetic product phytosterols in the skin (Tonello, 2006). 3) An exogenous source: Absorption of oxysterols from the diet, although the contribution of dietary COPs and POPs to the human plasma and tissues is still unclear.

\section{Endogenous sources of oxysterols}

\section{Cholesterol and phytosterols in the diet}

Cholesterol is found in animal food products such as eggs, milk, cheese, dairy products, red meat (beef, pork), ham, liver, fish and seafood. The American Heart Association recommends an intake of less than $300 \mathrm{mg} /$ day of cholesterol for healthy people. A European Prospective Investigation into Cancer (EPIC) study in Norfolk revealed that cholesterol mean intake was $260 \mathrm{mg} /$ day (Andersson et al., 2004). However, the intake range was 150-450 mg/day (Escurriol et al., 2010).

Phytosterols are synthesized by plants; hence we obtain them from the diet. The main sources of phytosterols are oils, spreads, nuts and seeds, and in lesser quantity in cereals and bakery products, vegetables and fruits (Conchillo et al., 2005a). In 2004, in the EPIC study developed in Norfolk, the estimated dietary intake of phytosterols ranged from $178 \mathrm{mg} /$ day to $463 \mathrm{mg} /$ day (Andersson et al., 2004). Later, in a study carried out in Germany the estimated dietary intake was 150-400 mg/day (Kuhlmann et al., 2005). Recently, another EPIC study carried out in Spain reveals that phytosterol mean intake is around $315 \mathrm{mg} /$ day (Escurriol et al., 2010). In general, the consumption of plant sterols in Asian cultures (including algae in their diets) and vegetarians is much higher. However, to get a significant reduction (10-15\%) of serum cholesterol a 
consumption of 2-3 g/day of phystosterols is required (Katan et al., 2003). This is one of the reasons why many phytosterol-enriched foods have been commercialised since 1995, when the first enriched fat yellow spread was launched. With the inclusion of these enriched foods in the diets, the dietary intake of phytosterols increases (Conchillo et al., 2005a; Kuhlmann et al., 2005).

\section{Cholesterol and phytosterol absorption}

Cholesterol is preferentially absorbed $(56-60 \%)$ by the human intestine in comparison to phytosterols, probably because of the different side chain structure (Bosner et al., 1999). Different absorption rates have been described for plant sterols, mainly depending on the sterol nucleus and the length of the side chain. Absorption is about $10 \%$ for campesterol and about $4-7 \%$ for sitosterol (Salen et al., 1992; Heinemann et al., 1993; Lütjohan et al., 1995) whereas lower rates were shown by Ostlund et al. (2002), who reported absorptions of $0.5 \%$ and $1.89 \%$ for sitosterol and campesterol, respectively, using dual stable isotopic tracers.

\section{Sterol transformation in vivo}

Dietary and endogenous cholesterol and dietary phytosterols are transformed into different metabolites in human cells. Oxidation of sterols occur following different pathways: non-enzymatic (provoked by radical mechanism) and enzymatic oxidations. The non-enzymatic ones mainly affect the sterol ring while the enzymatic ones react in the side chain of sterol structures (Ryan et al., 2009). However, there are some exceptions: $25-\mathrm{HC}$ and $7 \mathrm{a}-\mathrm{HC}$ can be generated by both metabolic pathways.

\section{a) Non-enzymatic oxidation}

Cholesterol is attacked by reactive oxygen species (ROS) abstracting an allylic hydrogen atom at C-7 of the sterol ring. The radical generated can react with oxygen to form a cholesterol peroxyl radical, which further reacts abstracting a hydrogen and generates the relatively stable cholesterol $7 \alpha / \beta$ - hydroperoxides (Brown and Jessup, 
2009). At this point, hydroperoxides may continue oxidizing non-enzymically or enzymes will reduce them to epoxycholesterols. The non-enzymatic oxidation generates $7 \alpha / \beta-\mathrm{HC}$ and $7-\mathrm{KC}$, which are the major non-enzymatic oxysterols present in most tissues (Fig. 2) (Brown and Jessup, 2009). 7a/ß-hydroxy and 7-keto derivatives of phytosterols are also formed by auto-oxidation in in vitro studies (Lampi et al., 2002; Grandgirard et al., 2004c).

$<$ Insert Figure 2>

Regarding in vivo experiments, it is suggested that POPs may be also formed by non-enzymatic oxidation reactions, although no evidence is still available concerning human studies (Hovenkamp et al., 2008). Aringuer and Enroth (1974) reported the autooxidation of sitosterol in rat liver fractions, forming $\beta$-epoxysitosterol in 3 to 4 fold excess over a-epoxysitosterol. Both epoxydes were susceptible for conversion into sitostanetriol. On the other hand, Grandgirard et al. (2004b) also in a study carried out with rats, showed that sitostanetriol and campestanetriol were not formed in vivo from phytosterols.

\section{b) Enzymatic oxidation}

24-, 25- and 27- HCs are generated by enzymatic side-chain hydroxylation of cholesterol (Rozner and Garti, 2006). Sterol 27-hydroxylase (CYP27A1) and cholesterol 24-hydroxylase (CYP46A1) are P450 enzymes expressed in liver and macrophages, and neural cells of the brain and retina, respectively (Björkhem et al., 1998; Brown and Jessup, 2009). They catalyse the hydroxylation reactions to form $27-$ and 24- HCs. Cholesterol 25-hydroxylase (Ch25h) is the enzyme responsible for generating 25-HC (Fig. 2) and it is expressed at very low levels. Nevertheless, it is very interesting, since its product $(25-\mathrm{HC})$ regulates the sterol regulatory element binding protein (SREBP) for cholesterol synthesis (Russell, 2000). Non-enzymatic oxidation of 25-HC has also been described (Smith, 1981), although the main source of this oxysterol is the enzymatic oxidation. Similarly, $7 \alpha-\mathrm{HC}$ can be enzymatically generated 
(Rozner and Garti, 2006) by 7a-hydroxylase and 7-ketone dehydrogenase (Smith, 1996).

In addition, there are some enzymes (5a,6a-epoxydase) that reduce hydroperoxides to 5,6-ECs. These ECs can be further converted to their triol end products via hydration in an acidic environment (Tai et al., 1999).

With regard to POPs, hydroxylases (Aringer et al., 1976) and other enzymes could be involved in their oxidation. Nonetheless, the studies in this field are limited (Hovenkamp et al., 2008).

The main oxysterol structures are shown in Figure 3.

$<$ Insert Figure 3>

\section{Phytosterol oxidation in the skin}

It was pointed out that POPs can be synthesized in the human skin by UV radiation (Tonello, 2006). Currently, several cosmetic products are enriched with or composed of phytosterols, which are absorbed by the skin. With this, UV light could catalyse the oxidation reactions of the plant sterols. However, there is a lack of evidence in this field and further studies are required.

\section{Exogenous sources of oxysterols}

\section{$\underline{\text { COPs and POPs in the diet }}$}

All foods containing cholesterol and phytosterols are susceptible to oxidation before entering the organism; especially those which have been exposed to heating treatments in the presence of oxygen or have been stored for long periods subjected to sunlight and oxygen. Hence, the source of oxysterols may be exogenous too (Guardiola et al., 2002; Leonarduzzi et al., 2002).

Lipid oxidation reactions not only usually cause food spoilage from the sensory point of view, but also induce chemical changes that might compromise their safety for consumption. Several studies have demonstrated that the same oxidation reactions as 
in endogenous pathways occur in foods, mainly during heating treatments and longterm storage. COPs and POPs have been detected in different groups of foods, such as oils, dairy products, eggs and egg products, meat and meat products, seafood and seafood products and several enriched food products (Table 1). Specifically, the amount of COPs in meat products ranges from $0.1 \mu \mathrm{g} / \mathrm{g}$ (beef) to $18.7 \mu \mathrm{g} / \mathrm{g}$ (mortadella), while in seafood products up to $19.4 \mu \mathrm{g} / \mathrm{g}$ (Brazilian Sardines) and 33.6 $\mu \mathrm{g} / \mathrm{g}$ (anchovies). For butter and spread, the content of oxysterols is around 13-27 $\mu \mathrm{g}$ COPs per gram and $13 \mu \mathrm{g}$ POPs per gram, respectively. For instance, in a portion of $25 \mathrm{~g}$ of these products, $<0.68 \mathrm{mg}$ of COPs would be consumed in the case of butter, in contrast to $0.33 \mathrm{mg}$ of POPs per $25 \mathrm{~g}$ of spread. The amount of POP consumed in $25 \mathrm{~g}$ of phytosterol-enriched spread would be much higher $(1.16 \mathrm{mg})$.

It has been demonstrated that while cholesterol and phytosterol oxidation products are similar, when heat-treated under similar conditions, COP concentrations

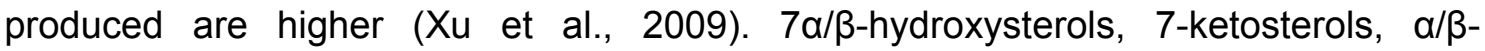
epoxysterols, and triols are the most detected oxidation products (Grandgirard et al., 2004c; Soupas et al., 2004; Johnsson and Dutta, 2006; Menéndez-Carreño et al., 2008b). Nonetheless, some authors have also quantified 24- hydroxystigmasterol, 25HC, 19-HC and 20a-HC (Echarte et al., 2001; Conchillo et al., 2005b; Johnsson and Dutta, 2006).

$<$ Insert Table 1>

The amount of oxysterols may be very heterogeneous in the same type of food. There are several factors that influence the formation of cholesterol and phytosterol oxidation products. Hence, it is of great interest to study the implication of these factors and to avoid them in order to decrease oxysterol concentrations in foods. 


\section{Factors influencing oxysterol concentrations in the diet}

\section{a) Heat treatment}

Heat treatments have marked effects on the rate of lipid auto-oxidation. Increasing temperature produces greater concentrations of free radicals due to the acceleration of the propagation reactions and lipid hydroperoxide decomposition. These free radicals promote the initiation and propagation of lipid auto-oxidation (Soupas et al., 2004). The oxidation reaction is directly related to the temperature of the heat treatment. Commercial stigmasterol treated at $100^{\circ} \mathrm{C}$ for seven days was less oxidized than the same sample treated at $180^{\circ} \mathrm{C}$ for 1 hour (Kemmo et al., 2005). Similarly, after treating commercial cholesterol and $\beta$-sitosterol at $150^{\circ} \mathrm{C}$ for 60 minutes, COPs and POPs were detected, but not at $120^{\circ} \mathrm{C}$ (Xu et al., 2009) or $100^{\circ} \mathrm{C}$ (Yen et al., 2010).

Studies developed with food samples, also show a direct relation between heat intensity and oxysterol formation. Higher contents of COPs were quantified in roasted salmon treated at $200^{\circ} \mathrm{C}$ for 30 minutes compared with the fried samples $\left(180^{\circ} \mathrm{C}\right.$-four minutes). The oxidation was proportional to the acidity index (Echarte et al., 2001). In addition, chicken and beef samples treated in the microwave (900W-three minutes; internal temperature of the samples at the end of the process: $100^{\circ} \mathrm{C}$ ) formed more cholesterol oxidation products than the ones fried with olive oil $\left(180^{\circ} \mathrm{C}\right.$-six minutes; internal temperature: $85-90^{\circ} \mathrm{C}$ ) (Echarte et al., 2003).

Nevertheless, under drastic heating conditions such as $180^{\circ} \mathrm{C}$ for two hours in presence of oxygen, the level of oxidation is so high that it degrades the formed COPs and POPs that formed from cholesterol and $\beta$-sitosterol pure standards, respectively (Xu et al., 2009) and stigmasterol standards (Menéndez-Carreño et al., 2010). A specific example of this was found in phytosterol-enriched milk which showed higher oxysterol levels post-treatment under microwave conditions for 1.5 minutes than for two 
minutes (Menéndez-Carreño et al., 2008b), suggesting that oxysterols suffer further oxidation and degradation processes.

Recently, higher concentrations of POPs were found in crude hazelnut oil than in the refined (Azadmard-Damirchi and Dutta, 2009). These results suggest that heat treatment in refining processes induces not only the formation of POPs, but also their degradation.

\section{b) Storage}

The effect of packaging on the oxidation reactions of sterols have been widely studied, since light, room temperature and presence of oxygen are critical factors in degradation processes.

Regarding COPs, a 2-month vacuum packaging of Milano-type sausages was found to be less efficient in controlling the COP formation than a 2-month protective atmosphere storage, detecting amounts of $1.90 \mu \mathrm{g} / \mathrm{g}$ and $1.37 \mu \mathrm{g} / \mathrm{g}$ of COPs, respectively (Zanardi et al., 2002). Similar results were obtained in other studies (Conchillo et al., 2005b; Valencia et al., 2008), showing that the lack of oxygen in the modified atmosphere packaging is greater than in the vacuum one, and therefore the protection of food samples from oxidation is superior. Also, cooked samples stored under frozen conditions were found to suffer more oxidation processes than raw ones (Conchillo et al., 2005a), demonstrating that cooking promotes cholesterol oxidation during storage.

With regard to POPs, they could be generated by photooxidation of the sterol ring mainly by sunlight, although artificial UV and irradiation also induce oxidation (Zhang et al., 2006). These results show that photooxidation depends on the dose rate (length of exposure); shorter but more intense treatments have lower oxidation effects. However, intense treatments could further oxidize POPs, similar to the effect of drastic temperatures in heat treatments. Hence, the effect of light in the formation of POPs should be extensively studied. 


\section{c) Matrix}

Besides food processing (heat treatment) and storage, the matrix in which sterols are contained has a great influence on oxidation reactions. There is a correlation between the degree of saturation of the lipid matrix and the sterol oxidation rate. Pure sterols are oxidized to a greater extent than sterols when contained in unsaturated and saturated matrix (Xu et al., 2009). Comparing the unsaturated and saturated matrix, in the former, the sterol oxidation rate was lower at high temperatures $\left(>140^{\circ} \mathrm{C}\right)$, probably owing to the facility of unsaturated fatty acid to oxidation, which protects sterols from oxidation. However, at low temperatures $\left(<140^{\circ} \mathrm{C}\right)$, the oxysterol formation was higher in the unsaturated matrix. The mechanism for this effect is not clear, but it seems to be that sterols react more rapidly in a matrix in which oxidation occurs more easily (Soupas et al., 2004).

The omega-6/omega-3 fatty acids rate (W6/W3) is also related to cholesterol oxidation. Chicken and roasted salmon samples have higher W6/W3 ratios than beef, raw and fried salmon samples, respectively. In addition, chicken and roasted salmon samples have been shown to generate greater amounts of COPs than other samples (Echarte et al., 2001; 2003). Yen et al. (2010) observed that $500 \mu \mathrm{g} / \mathrm{mL}$ of conjugated linoleic acid (CLA) when added to cholesterol standards, prevented cholesterol from oxidation at $150^{\circ} \mathrm{C}$.

In addition, the different effects of oil and oil-water emulsion matrix have been studied in the formation of oxyphytosterols. The phytosterol oxidation rate in bulk oil have been found to be lower than the one in the oil-water emulsion (Cercaci et al., 2006), suggesting that oil-water surface allows more interactions with aqueous phase prooxidants.

Finally, a number of studies have revealed that the addition of antioxidant to the food matrix can prevent cholesterol and phytosterol oxidation at high temperatures. Xu et al. (2009) observed that $200 \mathrm{ppm}$ of natural and synthetic antioxidants protect 
cholesterol and $\beta$-sitosterol standards against oxidation at $180^{\circ} \mathrm{C}$; in addition, natural antioxidants ( $\alpha$-tocopherol, quercetin and green tea catechins) were stronger than the synthetic butylated hydroxyl toluene (BHT) inhibiting COP and POP generation. D'Evoli et al. (2006) showed that rosemary (Rosmarinus officinalis, L.) prevents the formation of sitosterol oxides in extra virgin olive oil at $180^{\circ} \mathrm{C}$. In a comparative study, fewer oxysterols were formed in green tea extract-enriched rapeseed oil than in rosemary and BHT-enriched ones. However, the POP content in rapeseed oil without antioxidants was higher than in the oil enriched with each of the three antioxidants (Kmiecik et al., 2009).

\section{d) Esterification of phytosterols}

In commercial phytosterol-enriched foods, phytosterols are added as esters formed with fatty acids as their solubility enables an easier incorporation compared to non-esterified sterols (Brufau et al., 2008). Recent studies that compared the oxidation profiles of a phytosterol-enriched commercial spread and a non-enriched spread have shown that phytosterol oxidation rate was lower in the one that was enriched. These results suggest that natural phytosterol are oxidized more easily than the ones that were added (Conchillo et al., 2005a). With heat treatments, however, the oxidation seems to be greater in phytosteryl esters; during prolonged heating at $100^{\circ} \mathrm{C}$, phytosteryl esters were more reactive than free phytosterols, while at $180^{\circ} \mathrm{C}$, the formation of oxidation products was similar in both cases (Soupas et al., 2005).

\section{$\underline{\text { COP and POP absorption }}$}

Several studies in rats, mice, hamsters and rabbits have shown that different COP compounds can be absorbed in the intestines. The absorption of COPs is lower than that of cholesterol, probably due to the lower solubility of COPs in micelles, the lower susceptibility to esterification in enterocytes and the cytotoxic effects in mucosal cells which could explain the reduced lymph flow in rats that had been given COPs 
(Osada et al., 1994). Also, each type of COP is absorbed to different degrees; $7 \beta-\mathrm{HC}$,

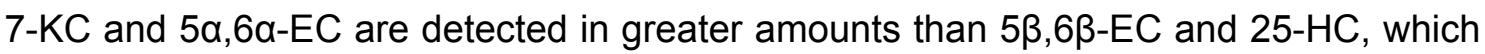
are not quantified in some studies done on rabbits and healthy humans (Osada et al., 1994; Linseisen and Wolfram, 1998; Vine et al., 1998).

A correlation exists between serum levels of COPs and their concentration in the diet. In rabbits that had been fed with COP-enriched diet, increased concentrations of COPs in plasma were found compared to those in the control diet group (Vine et al., 1998; Ubhayasekera et al., 2010a). Also, a diet containing highly oxidized lipids has been found to significantly increase the contents of oxycholesterols in meat, liver and plasma of chickens (Ubhayasekera et al., 2010b). These authors concluded that meat products from animals fed a diet containing higher levels of oxidized lipids may result in higher ingestion of oxycholesterols by humans.

Similarly, studies carried out in healthy humans have proven that after a diet containing $400 \mathrm{mg}$ of $\alpha-E C$, serum $\alpha$-EC can be detected, in comparison with the control group in which a-EC was not quantified (Staprans et al., 2003). Linseisen and Wolfram (1998) have found that the intake of parmesan cheese and salami (providing $0.84 \mathrm{mg}$ of unesterified COP and $2.64 \mathrm{mg}$ of COP acyl esters) raises plasma COP levels. Free oxidized cholesterol concentration increased three hours after the meal, but with very high interindividual variation. In contrast, total COP levels in plasma were up to 100 -fold higher $6-8$ hours after the intake of salami and parmesan, while the variation was lower (Linseisen and Wolfram, 1998).

Regarding POP absorption, results from animal studies have suggested that similar to phytosterols, there is a rise in plasma POP concentrations after a dietary intake of POPs. In hamsters that had been fed with 2500 ppm of POPs in the diet, $803.3 \mathrm{ng} / \mathrm{mL}$ of POPs were found compared with only $32.6 \mathrm{ng} / \mathrm{mL}$ of POPs in the control group. In the aorta, kidney and heart lipids, the phytosterol oxidation products were up to 26 -fold higher with a 2500 ppm POP diet than with the control diet. In liver lipids, the increase was up to 350-fold (Grandgirard et al., 2004d). 
There is a relation between the phytosterol from which the oxidized form originates and the absorption of the oxidized derivatives. In a study carried out by Grandgirard et al. (2004d), oxycampesterols represented $20-30 \%$ of the identified POPs in the tissues: this is greater in proportion than in the diet $(12.7 \%)$ and is probably due to a better absorption. In other studies, lymphatic recovery of campesterol oxidation products was greater than those of oxysitosterols (Grandgirard et al., 1999; Tomoyori et al., 2004). Therefore, it seems that the length of the side chain of phytosterol oxidation products is linked to their absorption; the longer the side chain, the lower the absorption level. Thus, oxidized derivatives of stigmasterol were not identified in plasma and tissues (Grandgirard et al., 2004d).

In addition, the type of oxidation could be related to a different rate of absorption. $7 \beta$-hydroxycampesterol and $7 \beta$-hydroxysitosterol are the most abundant types of POPs in mice' and hamsters' plasma and tissues (Grandgirard et al., 2004d; Tomoyori et al., 2004), suggesting that these compounds are better absorbed. $\alpha$-epoxyphytosterols and 7-ketophytosterols are presented at lower levels, probably due to rapid metabolization to triols and other compounds (Grandgirard et al., 1999; 2004d). Hence, the main POPs in tissues are triols and 7 $\beta$-hydroxyphytosterols (Grandgirard et al., 2004d). However, when comparing the absorption of phytosterols with that of oxyphytosterols, the results obtained were controversial; in some cases phytosterol absorption was greater (Grandgirard et al., 1999), and vice versa in others (Tomoyori et al., 2004). Nevertheless, few studies have still measured the in vivo absorption of oxydized phytosterols (Ryan et al., 2009).

In summary, oxysterols can be incorporated in plasma and tissues through a diet containing oxidized sterols. Nevertheless, a part of absorbed oxysterols come from the liver, where phytosterols and cholesterol are oxidized enzymatically and nonenzimatically. Hence, in several studies, the sterol oxidation concentrations found in plasma and tissues are higher than those performed in the test diets (Linseisen and Wolfram, 1998; Grandgirard et al., 2004d). 


\section{Oxysterols in the organism}

\section{Distribution and metabolism}

Oxysterols incorporated through the diet or excreted by the liver can be absorbed in human intestines. Once the oxysterols enter the enterocyte, they can follow different routes as is explained below (Fig. 4).

$<$ Insert Figure 4>

\section{a) Return to the intestine by $A B C G 5$ and $A B C G 8$}

Part of the absorbed phytosterols and cholesterol are secreted back into the intestinal lumen by transporters ABCG5 and ABCG8 which are a subfamily of ATPbinding cassette transporters. Oxysterols might be pumped back into the gut through this route (Hovenkamp et al., 2008). However, there have not been any specific studies about the implication of ABCG5 and ABCG8 in oxysterol transport.

\section{b) Esterification and distribution}

Most oxysterols measured in plasma and tissues are predominantly esterified (Linseisen and Wolfram, 1998; Staprans et al., 2003), suggesting that they are good substrates for acyl-coA cholesterol acyl transferase (ACAT) in cells and lecitin cholesterol acyl transferasa (LCAT) in the circulation (Gill et al., 2008).

Once the ACAT in the enterocyte reacts with oxysterols, they are incorporated to chylomicrons and later to Very Low Density Lipoproteins (VLDL), Low Density Lipoproteins (LDL) and High Density Lipoproteins (HDL) (Staprans et al., 2003; 2005). Hence, oxysterols can be transported to different cells of the organism.

COPs amounts in chylomicrons, LDL and HDL increased $2 \mathrm{~h}$ after a COPenriched meal (400 mg of $\alpha-E C$ ), while little $\alpha-E C$ was detected in VLDL. COPs remained in chylomicrons until $8 \mathrm{~h}$, but at $72 \mathrm{~h}$ the circulating $\alpha$-EC was found mainly in LDL, and less in HDL (Staprans et al., 2003). This proves that the oxidized sterol products increased much more in LDLs than in other lipoproteins after the intake of a 
COP test diet. These results suggest that COPs may play an important role in atherogenesis, as it will be explained later in this text.

$7 \alpha / \beta-\mathrm{HCs}$ and $7-\mathrm{KC}$ are the most quantified oxysterols in lipoproteins and their concentrations are greater than those found in the test diets, suggesting that they are also synthesized endogenously (Linseisen and Wolfram, 1998; Vine et al., 1998).

As far as POPs are concerned, their presence in heart, kidney, aorta and other tissues demonstrates that these types of sterols are also transported in lipoproteins (Grandgirard et al., 2004d).

\section{c) Further reactions or metabolism}

Oxysterols can be metabolized or degraded to other compounds, mainly in the liver. Oxycholesterols are found to be further oxidized or reduced by enzymes. Some of them are key enzymes of the bile acid biosynthesis, such as 7a-hydoxylase and 27hydorxylase (Ryan et al., 2009). CYP27A1 can metabolize 7-KC to 27-hydroxylated-7ketocholesterol and further to water-soluble metabolites which can be eliminated from cells (Lyous and Brown, 2001; Larsson et al., 2007). On the other hand, 7-KC can also follow a reduction route, being converted to $7 \beta-\mathrm{HC}$ by $11 \beta$-hydroxysteroid dehydrogenase type1 (Schweizer et al., 2004; Larsson et al., 2007).

Cholesterol sulfotransferase enzyme (SULT2B1b) usually sulfates the $3 \beta$-hydroxil group of cholesterol, but oxysterols also have been found to be substrates of this enzyme (Fuda et al., 2007). SULT2B1b is expressed in retina, skin, platelets, liver and other tissues; hence, this route could be an important oxysterol excretion pathway (Higashi et al., 2004; Yanai et al., 2004; Fuda et al. 2007).

\section{Excretion}

Most of the oxysterols can be only eliminated from cells through specific membrane lipid transporters as a consequence of their hydrophobicity. Apart from the ABCG5 and ABCG8 transporters that pump back oxysterols to the intestine, there are other ATP-binding cassette transporters involved in oxysterol excretion. ABCA1 and 
ABCG1 are mainly located in the macrophages and liver to transport oxidized sterols and other molecules out of the cell (Brown and Jessup, 2009).

\section{Toxicity and pathological effects of oxysterols}

COPs are associated with the initiation and progression of major chronic diseases including atherosclerosis, neurodegenerative processes, diabetes, kidney failure, and ethanol intoxication (Sottero et al., 2009). They provoke an imbalance of the ratio between oxidative and reductive biochemical reactions (oxidative stress) which acts on all organism levels from cell signalling to disease expression through upregulation of inflammation, apoptosis and fibrosis.

COPs compared to unoxidized cholesterol have demonstrated stronger pathological and toxic effects by at least one to two orders of magnitude (Poli et al., 2004; Van Reyk et al., 2006). This difference could be explained by the presence of a further oxygen group, which renders COPs more polarity and water-solubility, hence enabling COPs to pass through lipophilic membranes and redistribute into cells more efficiently than cholesterol (Sottero et al., 2009). The implications of POPs in atherosclerosis, neurodegenerative processes and other chronic diseases are still unknown. However, they have been associated with cytotoxic and pro-apoptotic effects (Meyer et al., 1998; Adcox et al., 2001; McCarthy et al., 2005).

\section{Cytotoxicity and apoptotic effects of oxysterols}

The cytotoxic effects of COPs have been studied in the last 25 years in the macrophages, fibroblasts, vascular cells, cancer cells and smooth muscle cells (Peng et al., 1985; Raaphorst et al., 1987). It has been demonstrated that the mode of cell death is by apoptosis (O'Callaghan et al., 2001). To analyse the cytotoxic and apoptotic effects of COPs, several mechanisms such as cell viability, DNA fragmentation, lactate deshydrogenase leakage, mitochondria dehydrogenase activity, glutathione concentration and caspase activity have been used, (Adcox et al., 2001; 
O'Callaghan et al., 2001; Meynier et al., 2005; Prunet et al., 2005; Vejux and Lizard, 2009).

COPs in vitro were five times more cytotoxic than POPs (Meyer et al., 1998). This was also shown in other studies in which higher concentrations of POPs $(120 \mu \mathrm{M})$ were required for the same cytotoxic effects of $60 \mu \mathrm{M}$ of COPs (Adcox et al., 2001; Maguire et al., 2003; Roussi et al., 2005; 2006; 2007). However, POPs and COPs have different cytotoxic routes (Ryan et al., 2005). This difference was demonstrated when atocopherol, $\gamma$-tocopherol, and $\beta$-carotene antioxidants were protected against the cytotoxic effects of $7 \beta-\mathrm{HC}$, but not against the toxicity of POPs.

Several cytotoxic routes have been proposed for COPs: perturbation of the intracellular calcium levels, intracellular ROS overproduction, mitochondrial and lysosomal membranes modifications and polyamine metabolic perturbations (Roussi et al., 2006; 2007; Sottero et al., 2009). On the other hand, caspase-mediated pathways and glutathione depletion are suggested as POPs pro-apoptotic mechanisms (Maguire et al., 2003; Ryan et al., 2005). Recently, cytotoxic effects of $7 \beta-\mathrm{HC}$ and $7 \beta-$ hydroxysitosterol have been compared (Roussi et al., 2005; 2006; 2007). Both types of sterol oxides have been found to interact with plasma membranes; $7 \beta-\mathrm{HC}$ induced the permeabilization of mitochondrial membrane and the release of endonuclease $G$ to the nucleus. The expression of endonuclease G promotes DNA fragmentation and cell death. Moreover, $7 \beta-\mathrm{HC}$ enhances ROS formation in the mitochondria, which possibly destabilizes the lysosomal membrane. $7 \beta$-hydroxysitosterol also raised the permeabilization of mitochondrial membrane and the secretion of cytochrome $C$ to cytosol. Cytochrome C activates pro-apoptotic factors as well as the maturation of caspase- 3 and-9, which is intimately related to POP cytotoxic pathway. Furthermore, similar to $7 \beta-H C, 7 \beta$-hydroxysitosterol disrupts lysosomal membrane integrity.

Regarding different types of COPs and POPs, 7-hydroxy, 7-keto and triol derivatives are the most cytotoxic ones (Meynier et al., 2005; Ryan et al., 2005). 
Because of their pro-apopototic and cytotoxic effects, oxysterols could be applied to avoid carcinogenesis with interesting results. This pharmacological application has already been found in Chinese traditional medicine; antitumoral plants contain $7 \alpha / \beta$ hydroxysitosterol, 7a/ $\beta$-hydroxycampesterol and ketocampesterol (Schroeder et al., 1980; Chaurasia and Wichtl, 1987). There is no evidence of these components being pharmacologically active, but they could be responsible for anticarcinogenic effects (Hovenkamp et al., 2008).

\section{Pro-inflammatory effects of oxysterols}

Inflammation has been recently associated with several chronic diseases, such as obesity, atherogenesis and Alzheimer. As multiple molecules are implicated with pro- or anti-inflammatory effects, it is very difficult to study all the routes involved. Nevertheless, COPs have been proven to up-regulate the expression of various inflammatory molecules, including adhesion molecules, growth factors, cytokines and chemokines.

Regarding inflammatory molecules, $7 \alpha / \beta-\mathrm{HCs}$ and $7-\mathrm{KC}$ seem to induce intercellular adhesion molecule-1 (ICAM-1), vascular cell adhesion molecule-1 (VCAM1) and E-selectin (Lemaire et al., 1998; Romeo et al., 2004). An increase in the expression of transforming growth factor $\beta 1$ (TGF $\beta 1$ ), the main fibrogenic cytokine, giving rise to the progression of fibroesclerosis within the damaged arterial wall has been observed for a mixture of COPs (Leonarduzzi et al., 2001; 2005). The expression and synthesis of MCP-1 (monocyte chemotactic protein-1), the major chemokine for monocytes/macrophages, in cells of the macrophage lineage (U937 cell line), was also increased by a mixture of COPs, being this regulation dependent on a net increment of phosphorylation of extracellular signal-regulated kinase 1/2 (ERK 1/2 and nuclear factor KB (NF-kB) nuclear binding (Leonarduzzi et al., 2005).

Interleukin-8 (IL-8), which might be proatherogenic by recruiting $\mathrm{T}$ lymphocytes and monocytes in the arterial subendothelial space and by inhibiting expression of local 
tissue inhibition of metalloproteinase-1, is regulated by various COPs basically through a calcium-dependent phenomenon involving MEK/ERK $1 / 2$ pathway and activation of AP-1 (Rydeberg et al., 2003; Prunet et al., 2006; Erridge et al., 2007; Lemaire-Ewing et al., 2008; 2009; Sottero et al., 2009).

Also cholesterol oxides might induce atypical gene expression in neural cells that may contribute to the etiology or pathogenesis of inflammatory brain disease (Alexandrov et al., 2005).

The modulation of inflammation by POPs has been much less studied (Hovenkamp et al., 2008). A mixture of oxidized derivatives of $\beta$-sitosterol has shown an anti-inflammatory activity in a 12-O-tetradecanoylphorbol-13-acetate (TPA)-induced inflammation of ears in mice (Kimura et al., 1995). However, these positive effects, which have been found only for some oxyphytosterols, have to be confirmed.

\section{Atherosclerosis induced by oxysterols}

The first COPs were found in atheromatous plaques, suggesting the implication of oxysterols in atherogenic processes (Brooks et al., 1966). Moreover, several sterol oxidized products have been quantified in LDLs, which are directly involved in atherogenesis (Staprans et al., 2003).

There is growing evidence that suggests oxidized LDLs (oxLDLs) play a major role in the injury of endothelium. Its content in COPs serves as the reactive mediator of structural and functional changes of the vascular endothelium affected by atherosclerotic process (Guardiola et al., 1996; Leonarduzzi et al., 2002). Atherogenesis is principally caused by hypercholesterolemia and inflammation (Schroepfer, 2000; Steinberg, 2002). Oxidized LDLs are not recognized by LDL receptors, they are instead taken up by scavenger receptors on macrophages of arterial walls (Stocker et al., 2004). Oxidized LDLs generate lipid derived molecules (COPs, peroxidized fatty acids...) that accumulate in the vascular subintimal space. They produce monocytes adhesion and transmigration which conclude with the 
formation of foam cells. The proliferation of foam cells, in addition to inflammation and apoptosis, generates a fibrotic cap (atheromatous plaque). The instability and release of this plaque can result in thrombosis (Fig. 5) (Steinberg, 2002; Poli et al., 2009).

$<$ Insert Figure 5 $>$

Specifically, COPs are involved in various key steps of the atherogenic process:

1) Endothelial cell dysfunction (increasing permeability). 2) Adhesion and transmigration of monocytes (expression of cell adhesion molecules, chemokines and cytokines). 3) Generation of foam cells (differentiation of monocytes to macrophages). 4) Macrophages and smooth muscle cells interaction and extracellular matrix overproduction. 5) Inflammation and fibrotic cap formation. 6) Vascular apoptosis and extracellular matrix degradation (Poli et al., 2009).

Analysis of fibrotic plaques removed from human carotids demonstrated that, , 27-HC, 7-KC and 7ß-HC were accumulated (Garcia-Cruset et al., 1999; 2001). Zhou et al. (2000) found that plasma from catheterized patients showed much higher total free oxysterols than control ones, being the most abundant of those from autoxidation origin. Larsson et al. (2006) showed that increased levels of $7 \beta-\mathrm{HC}$ and $7-\mathrm{KC}$ may play an important role in the induction of oxidative stress in atheroma plaques by stimulating production of ROS and decreasing cellular antioxidants. Increased COPs levels (mainly $7-\mathrm{KC}$ and $7 \beta-\mathrm{HC}$ ) have been reported in disease states where oxidative stress was increased such as diabetes mellitus (Abo et al., 2000) or familial combined hyperlipidemia (Arca et al., 2007). In addition, significantly higher concentrations of blood COPs were found in the blood of diabetic and hypercholesterolemic patients than in the blood of control subjects (Szuchman et al., 2008). Seet et al. (2010) found that the levels of plasma $7 \beta-\mathrm{HC}, 27-\mathrm{HC}$ and $7-\mathrm{KC}$, as well as other oxidative markers, were elevated in patients of Parkinson disease. The use of COPs as biomarkers could improve the early diagnosis of the different diseases in which oxidative stress appears to be involved: neurodegenerative diseases, diabetes, obesity...With this information, 
specific antibodies against 7-KC have been developed, with the aim of detecting oxysterols in atherosclerotic lesions (Myoishi et al., 2007).

On the other hand, triol derivatives have been described as one of the most cytotoxic oxysterols to endothelial cells (Meynier et al., 2005). As was pointed out before, $\alpha-E C$ is readily metabolised to triol derivatives and these metabolites are one of the most abundant COPs in human plasma and tissues (Grandgirard et al., 2004d).

However, the implication of dietary COPs in atherogenesis is not clear. Recently, COP enriched diets have been associated with atherogenic effects in Apolipoprotein Edeficient mice (Staprans et al., 2000). Conversely, another study carried out on the same animal models showed that oxidized sterols in the diet do not induce atherogenesis (Ando et al., 2002). The reason for the apparent discrepancy between these studies is unknown but may reside in the different study conditions. Recently, Soto-Rodriguez et al. (2009) observed that dietary COPs caused an inflammatory process and promoted atherogenesis and atrophy of tissue in rats.

Furthermore, the role of some oxysterols in intracellular lipid accumulation that takes place in atherosclerotic processes is also under research. 7-KC has been demonstrated to be a potent apoptotic inducer, causing cytoplasmatic modifications, including a reversible formation of myelin figures. These are polar lipid-rich structures, containing high levels of phosphatidylcholine and sphingomyelin and localized in acidic compartiments, that characterizes phospholipidosis (Vejux et al., 2009).

As far as POPs are concerned, in vivo studies do not show atherogenic effects caused by these oxidized plant sterols (Ando et al., 2002; Tomoyori et al., 2004).

\section{Beneficial effects of oxysterols}

It appears that sterols oxidized in the ring are implicated in toxic effects, whereas sterols oxidized enzymatically in the side chain play important biological roles (Gill et al., 2008). 


\section{$\underline{\text { COPs in membrane structures and their effects on permeability }}$}

Cholesterol is required to build and maintain membranes, decreasing their fluidity and permeability and promoting the formation of special liquid-ordered microdomains that are known as lipid rafts. Because of their homology, COPs are also inserted in the membrane but, in general, their condensing and ordering capability is lower. However, it has been shown that depending on the composition of the phospholipid matrix, oxysterols may induce or inhibit membrane permeability (Sottero et al., 2009).

\section{$\underline{\text { Cholesterol homeostasis regulated by COPs }}$}

Several COPs are associated with the cholesterol homeostasis through different mechanisms:

\section{a) Sterol Regulatory Element Binding Protein (SREBP) blockade}

Sterol regulatory element binding protein (SREBP) is produced in endoplasmic reticulum (ER) and controls the expression of genes involved in cholesterol synthesis. It is bound to the SREBP-cleaveage activating protein (SCAP) which is like a cholesterol sensor; if cholesterol levels are low, SCAP releases SREBP and the gene transcription is stimulated. However, when cholesterol levels are high, Insig (insulin induced gene) protein retains SCAP-SREBP complex in ER and the gene transcription is inhibited. Moreover, cholesterol production may be stopped by the cholesterol binding to SPAC, when cholesterol levels are increased in ER.

Similarly, it has been shown that COPs can block SREBP-SCAP by their union with Insig protein. Specifically, 24(S),25-epoxycholesterol (24(S),25-EC) is bound to the Insig element and inhibits the synthesis of cholesterol (Lund et al., 1998; Gill et al., 2008).

b) Degradation of 3-hydroxy-3-methil-glutaryl-CoA (HMC-CoA) reductase

3-hydroxy-3-methil-glutaryl-CoA (HMC-CoA) reductase is one of the proteins expressed when SREBP reaches the nucleus for gene transcription. HMC-CoA 
reductase catalyzes the conversion of HMG-CoA to mavelonate, one of the steps in cholesterol synthesis. 27-hydroxycholesterol seems to degrade this enzyme, inhibiting cholesterol production (Lange et al., 2008).

\section{c) Oxycholesterol stimulate Liver X Receptor (LXR)}

24(S),25-EC is found to bind LXR, which regulates the transcription of a number of genes involved in lipid metabolism, including those of the $A B C$ transporters (Chen et al., 2007). Members of $A B C$ family transporters are implicated in the excretion of sterols and oxysterols from the cell, as was mentioned earlier. Therefore, when 24(S),25-EC binds LXR, cholesterol excretion will be stimulated.

\section{d) Sterol transport: stimulation and inhibition}

Some studies have demonstrated that oxysterols (24(S)-HC and 27-HC) could transport sterols to the liver regulating their incorporation to HDL (Björkhem et al., 1994; 1998; Lund et al., 1996). Conversely, other studies have showed that 7-KC inhibits the export of cholesterol to HDL, accumulating cholesterol in cells (Jessup et al., 2002).

It has been noticed that $24(\mathrm{~S}), 25-\mathrm{EC}$ plays an important role in cholesterol homeostasis, blocking SERBP and stimulating the transcription of $A B C$ transporters (Chen et al., 2007; Gill et al., 2008; Brown and Jessup, 2009). These effects in cholesterol homeostasis could also regulate oxysterol synthesis and degradation; stimulation of ACAT, inhibition of the incorporation to HDL and other mechanisms are proposed (Leonarduzzi et al., 2002).

\section{Possible beneficial effects of POPs}

Extensive literature data demonstrate the efficacy of phytosterols to decrease serum cholesterol in humans (Katan et al., 2003; Berger et al., 2004). Different mechanisms are involved: phytosterols are able to inhibit cholesterol absorption in the intestine competing with cholesterol in the formation of lipid micelles or precipitating 
cholesterol in the gut. Also, plant sterols activate LXR in order to increase cholesterol excretion to the intestinal lumen, and inhibit the ACAT enzyme from decreasing cholesterol esterification (Plat and Mensink, 2002; Plat et al., 2005). In this last paper, Plat et al. (2005) suggested that some POPs (those formed by enzymatic oxidation of the side chain) may be also involved in the modulation of cholesterol metabolism via LXR activation and increment of $A B C$ transporters expression. In any case, for LXR regulation by naturally present forms of oxyphytosterols less evidence is available (Hovenkamp et al., 2008).

On the other hand, studies developed in vitro with POPs revealed that they may induce an increase in plasma sex steroids and an acceleration of spermatogenesis (androgen effects) (Christiansion-Heika et al., 2007). In addition, an oxycampesterol (campestenone) has been found to reduce body weight gain, visceral fat deposition, serum triacyglycerols and blood glucose in mice and rats (Suzuki et al., 2002; Ikeda et al., 2006). However, these hypotheses still need to be deeply studied in humans (Ryan et al., 2009).

\section{Conclusion}

The world of oxysterols is a wide field and still needs a lot of research. It seems clear the implication of COPs in several toxic effects whereas in the case of POPs, there is a lack of scientific evidence in this sense. The commercialization of phytosterols enriched foods makes necessary the evaluation of the biological effects of POPs that can be formed from those plant sterols. Also some data suggest that this type of compounds could be related to biological positive effects, so the balance of all these effects deserves to be studied. 


\section{Acknowledgements}

Authors would like to thank "Programa Consolider-Ingenio 2010 CARNISENUSA CSD2007-00016", the "Proyecto AGL2008-01099/ALI" (Ministerio de Ciencia e Innovación), PIUNA (Plan Investigador de la Universidad de Navarra) and Universidad de Navarra - Grupo Santander for their contribution to the financial support of this work. Miss Tsing Ling Tan is acknowledged for the English revision of the manuscript. 


\section{Tables and Figures}

Figure 1

Fig. 1: Cholesterol and main phytosterols' structures.<smiles>CC(C)CCC[C@@H](C)C1CCC2C3CC=C4CC(O)CC[C@]4(C)C3CC[C@@]21C</smiles><smiles>CCC(CC[C@H](C)C1CCC2C3CC=C4C[C@@H](O)CC[C@]4(C)C3CCC21C)C(C)C</smiles>

Sitosterol

Cholesterol<smiles>CC(C)C(C)CC[C@@H](C)C1CCC2C3CC=C4C[C@@H](O)CC[C@]4(C)C3CC[C@@]21C</smiles>

ol<smiles>CCC(/C=C/[C@@H](C)C1CCC2C3CC=C4C[C@@H](O)CCC4(C)C3CCC21C)C(C)C</smiles>

Stigmasterol 


\section{Figure 2}

Fig. 2: Enzymatic and non-enzymatic production of the main cholesterol oxidation products (COPs) from cholesterol. In general, COPs oxygenated on the sterol ring are produced non-enzymatically, while COPs oxygenated on the side-chain require enzymes for their formation. 25- and 7a- hydroxycholesterols can be generated by both metabolic pathways.

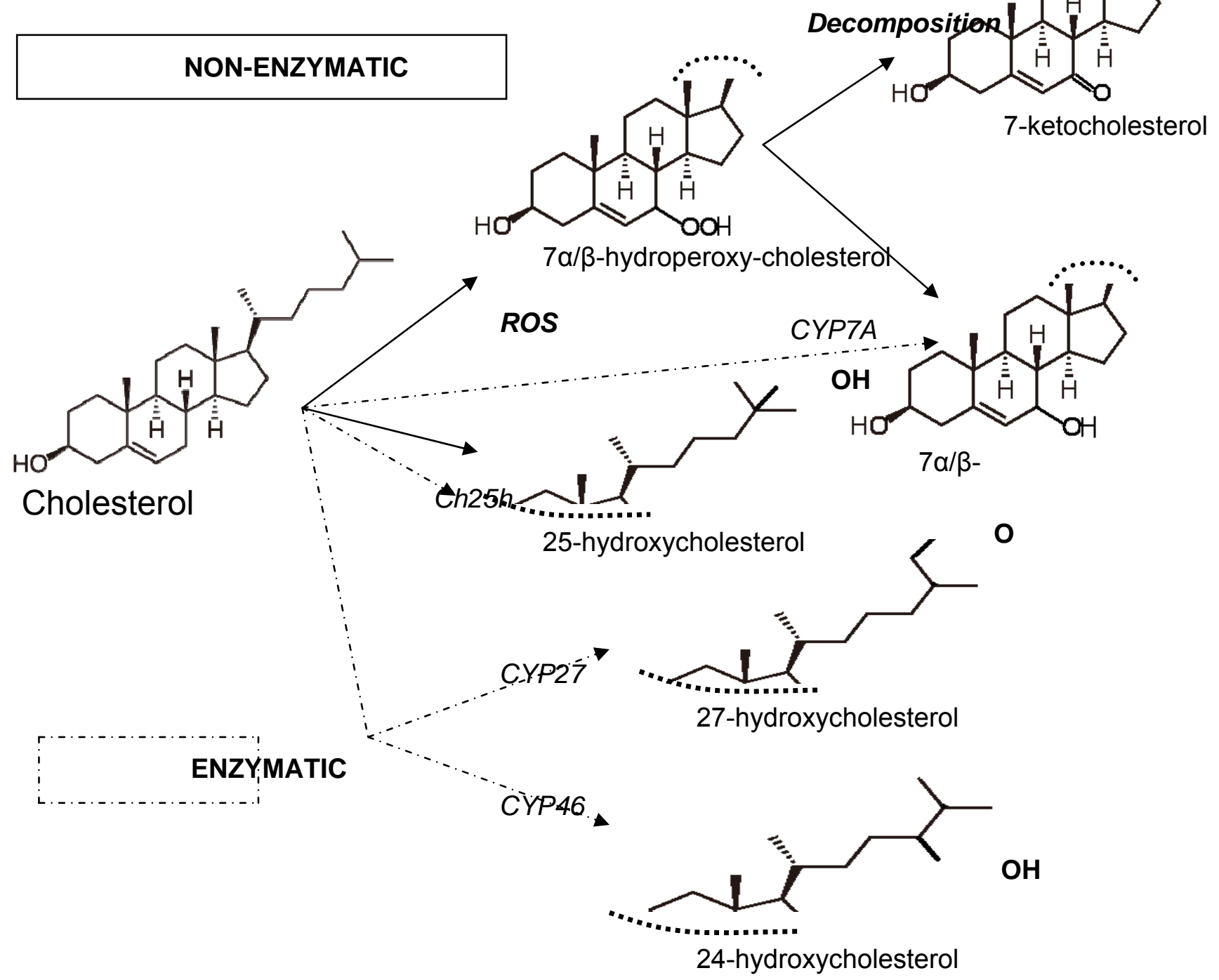


Figure 3

Fig. 3: Main oxysterol structures.
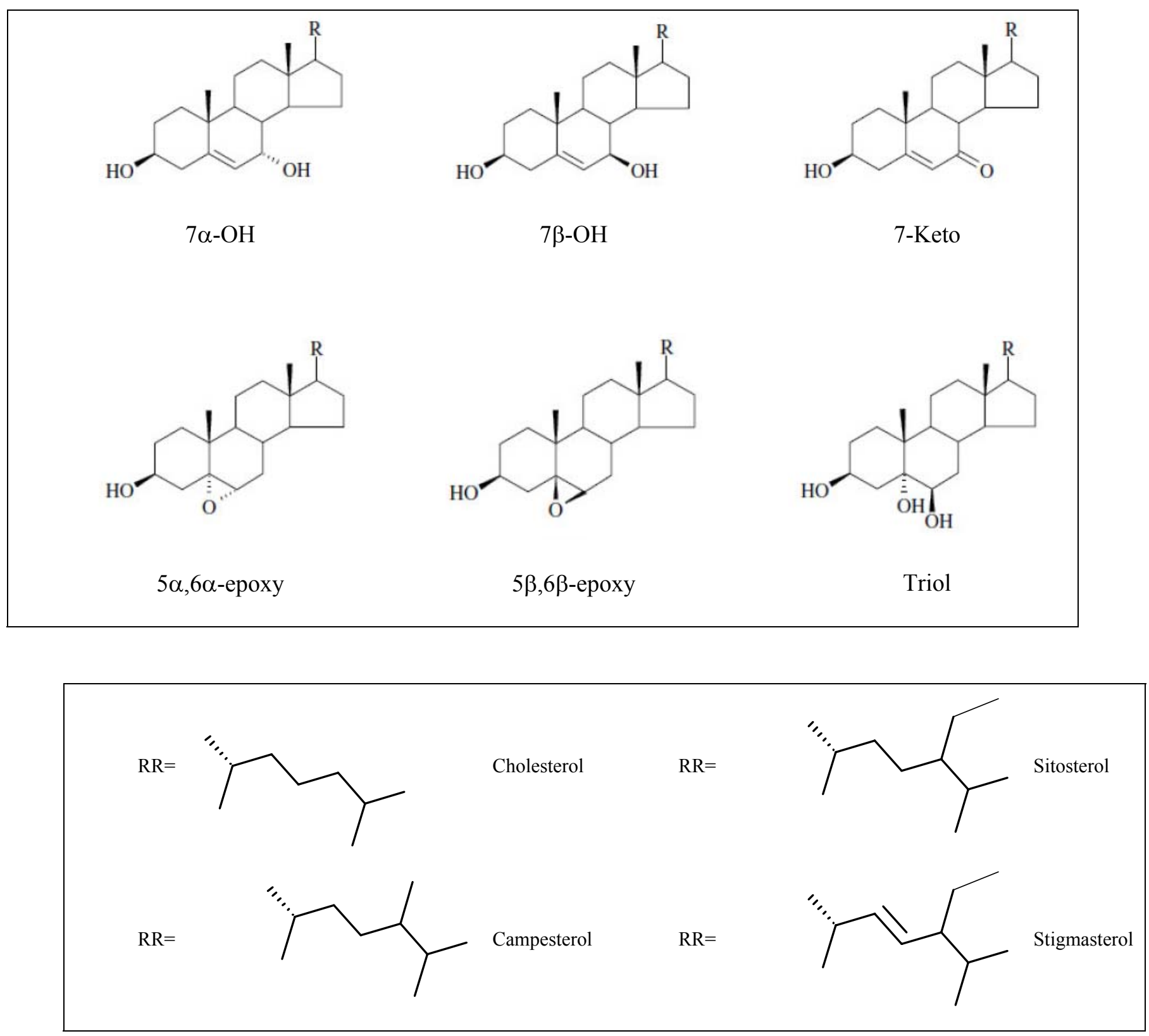


\section{Figure 4}

Fig. 4: Sterol and probably oxysterol absorption, esterification and incorporation into chylomicrons. NPC1L1: lipid micelle transporter; ABC: ATP Binding Cassette transporters; ACAT: Acyl-coA Cholesterol Acyl Transferase; TG: Triglycerides; MPT: Microsomal TG transfer protein; QM: Chylomicrons; HDL: High Density Lipoprotein; SR-B1: Scavenger Receptor type B. Source: Menéndez-Carreño, 2009.

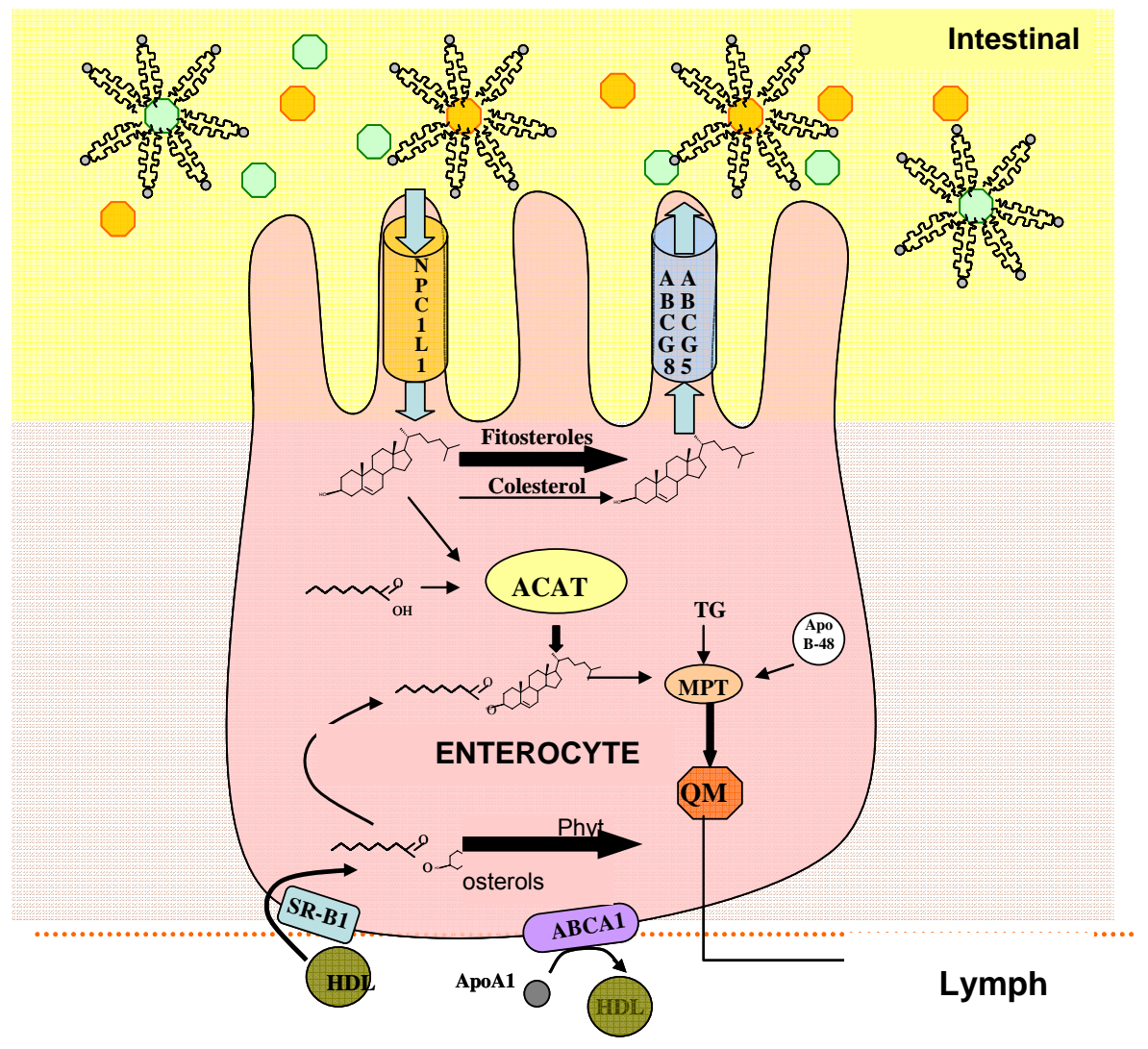


Figure 5

Fig. 5: Scheme of atherogenic process. LT: T lymphocyte; LDL: Low Density Lipoproteins. Source: Menéndez-Carreño, 2009.

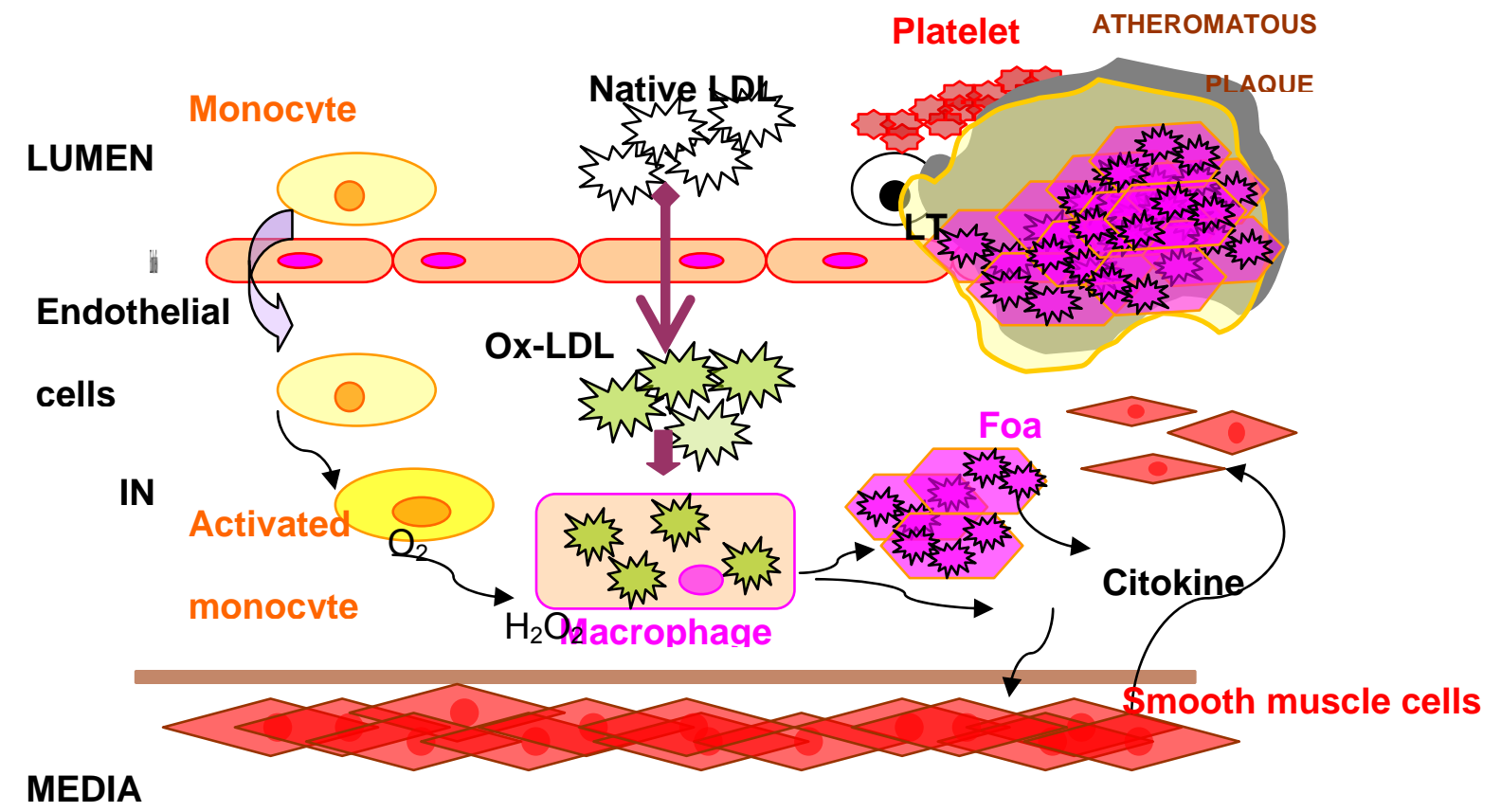




\section{Table 1}

Table 1: Quantity of phytosterol oxidation products (POPs) and cholesterol oxidation products (COPs) in different types of foods.

St: Stigmasterol oxides; Si: $\beta$-sitosterol oxides; C: Campesterol oxides; B: Brassicasterol oxides; Sol:

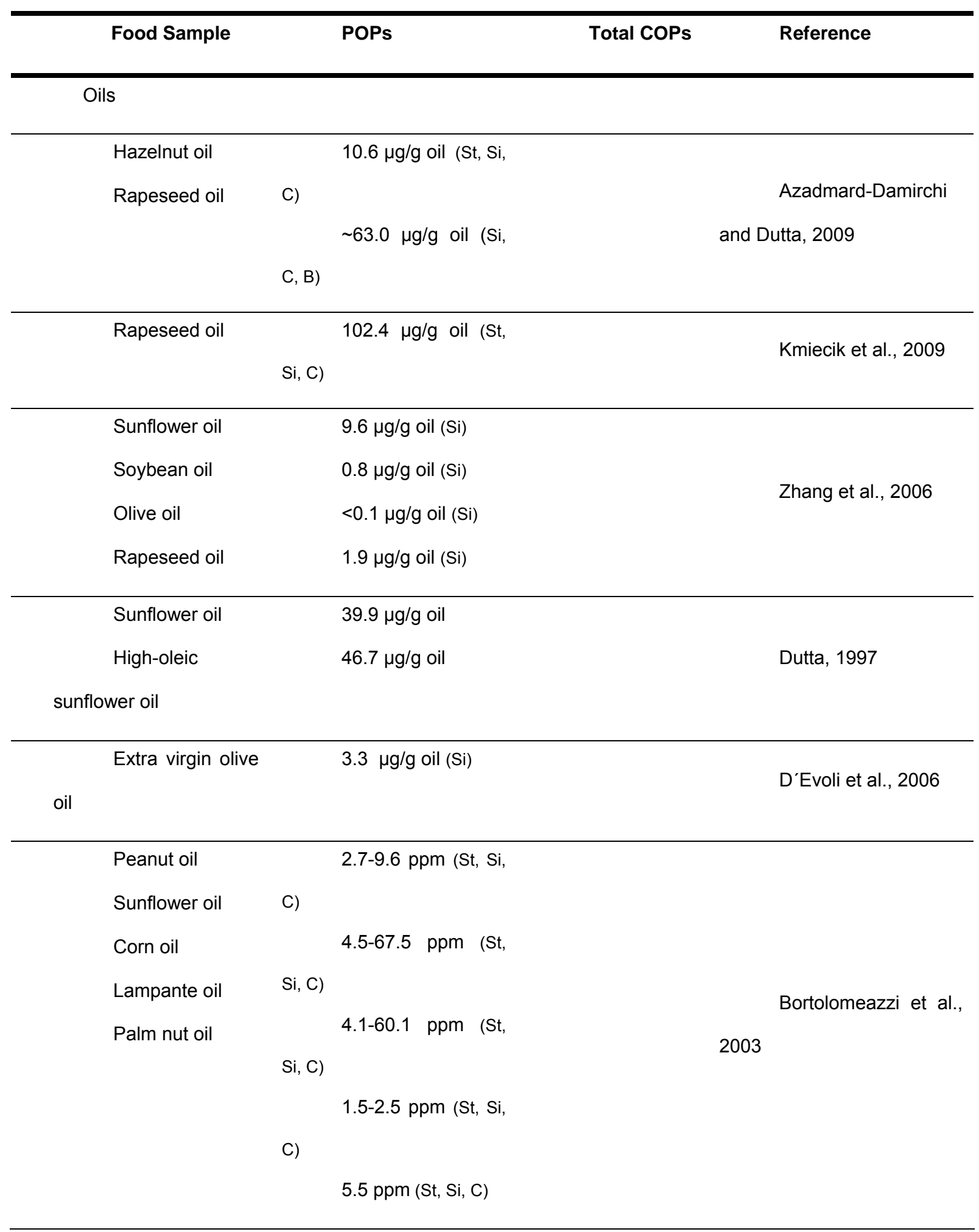




\begin{tabular}{lccc}
\hline Non-enriched & $13.3 \mu \mathrm{g} / \mathrm{g}(\mathrm{St}, \mathrm{Si}, \mathrm{C})$ & Conchillo & et al., \\
spread & & $2005 \mathrm{~b}$ & \\
\hline
\end{tabular}

Dairy products

\begin{tabular}{ccc}
\hline Whole milk & $1.1 \mu \mathrm{g} / \mathrm{g}$ & Angulo et al., 1997 \\
powders & & \\
\hline Butter & $\mu \mathrm{gg} / \mathrm{g}$ & Pie et al., 1990 \\
& & \\
\hline Ghee (fresh) & $259.0 \mu \mathrm{g} / \mathrm{g}$ & Jacobson, 1987 \\
\hline Egg and egg
\end{tabular}

products

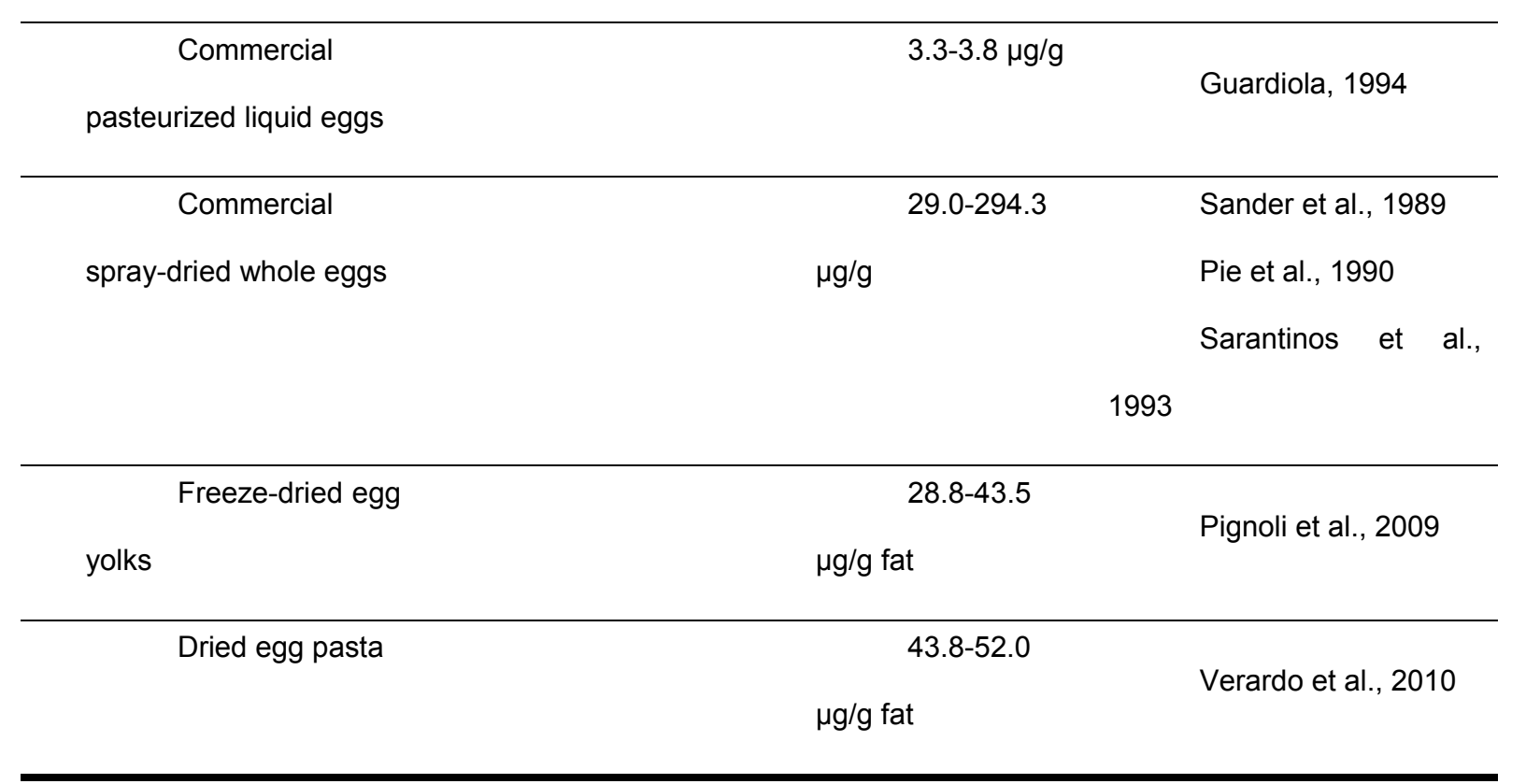

Meat and meat

products

\begin{tabular}{lll}
\hline Beef & $0.1 \mu \mathrm{g} / \mathrm{g}$ & Boselli et al., 2009 \\
\hline Beef & $<8.0 \mu \mathrm{g} / \mathrm{g}$ & Ferioli et al., 2010 \\
\hline Minced beef & $3.4 \mu \mathrm{g} / \mathrm{g}$ & Pie et al., 1991 \\
Minced pork & $2.2 \mu \mathrm{g} / \mathrm{g}$ & \\
Minced veal & $1.8 \mu \mathrm{g} / \mathrm{g}$ & \\
\hline Chicken & $4.0 \mathrm{ppm}$ & Echarte et al., 2003 \\
Beef & $2.3 \mathrm{ppm}$ &
\end{tabular}




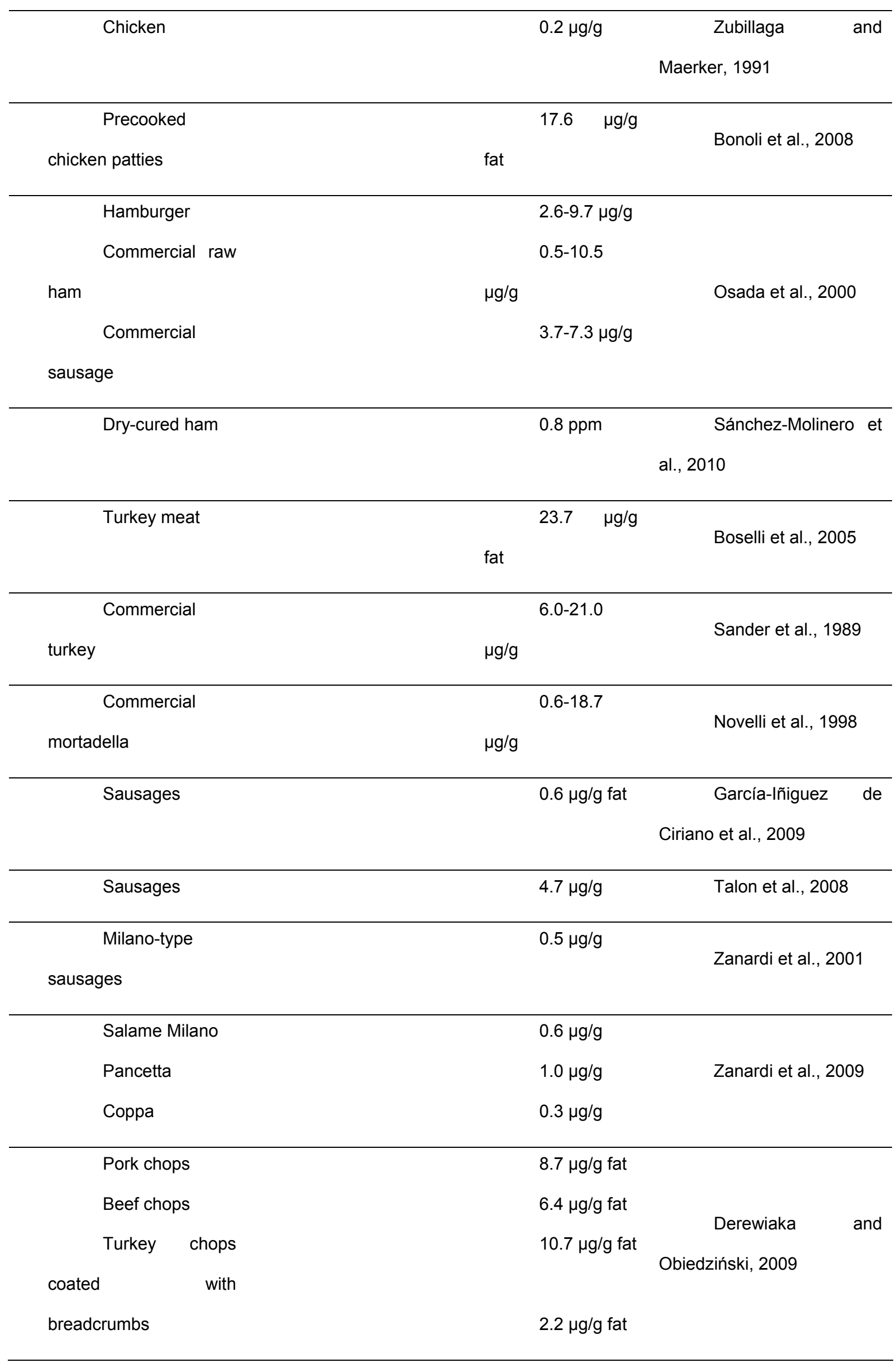




Cordon blue
chops coated with
breadcrumbs
Machaca (dried-
beef) $\quad$ mg/100 g
Chicharrón
(deep-fried-pork rinds)

\section{Seafood and seafood products}

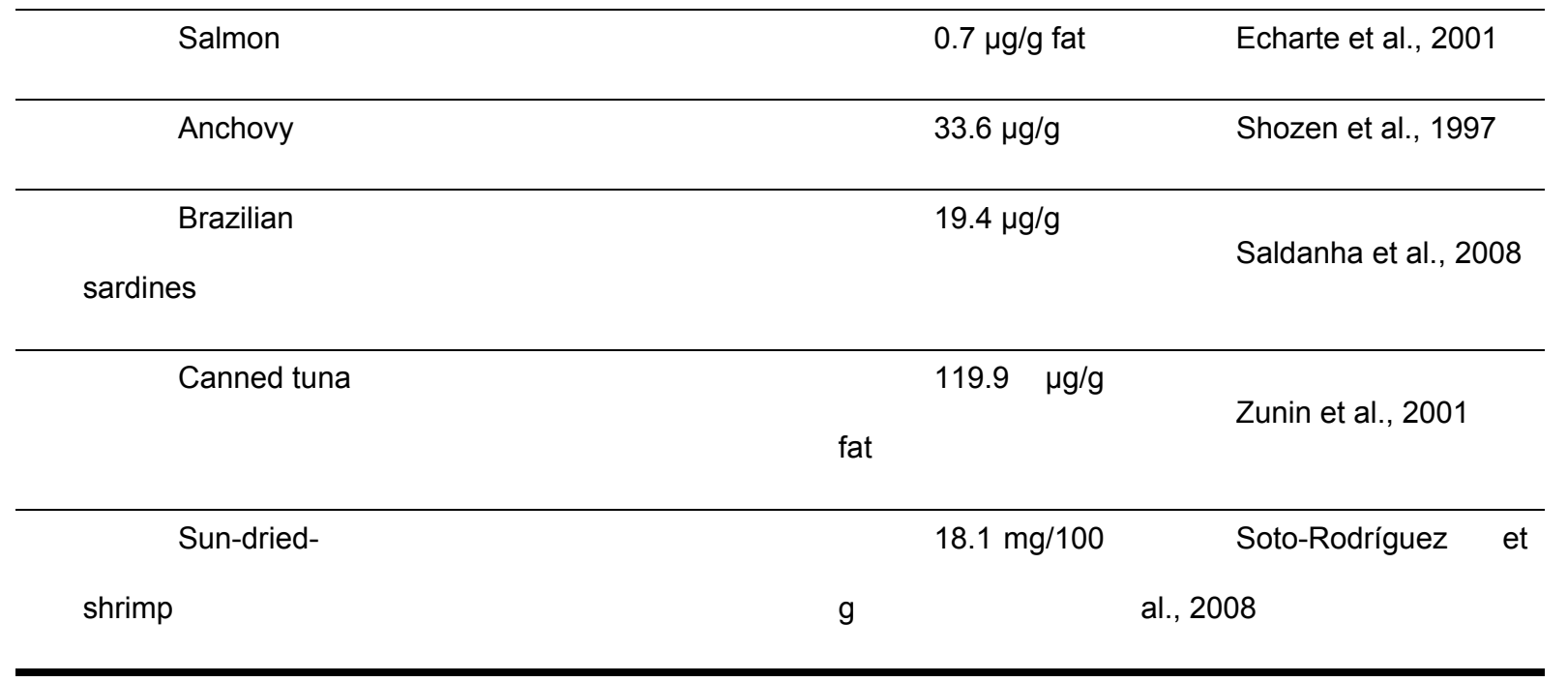

Other foods

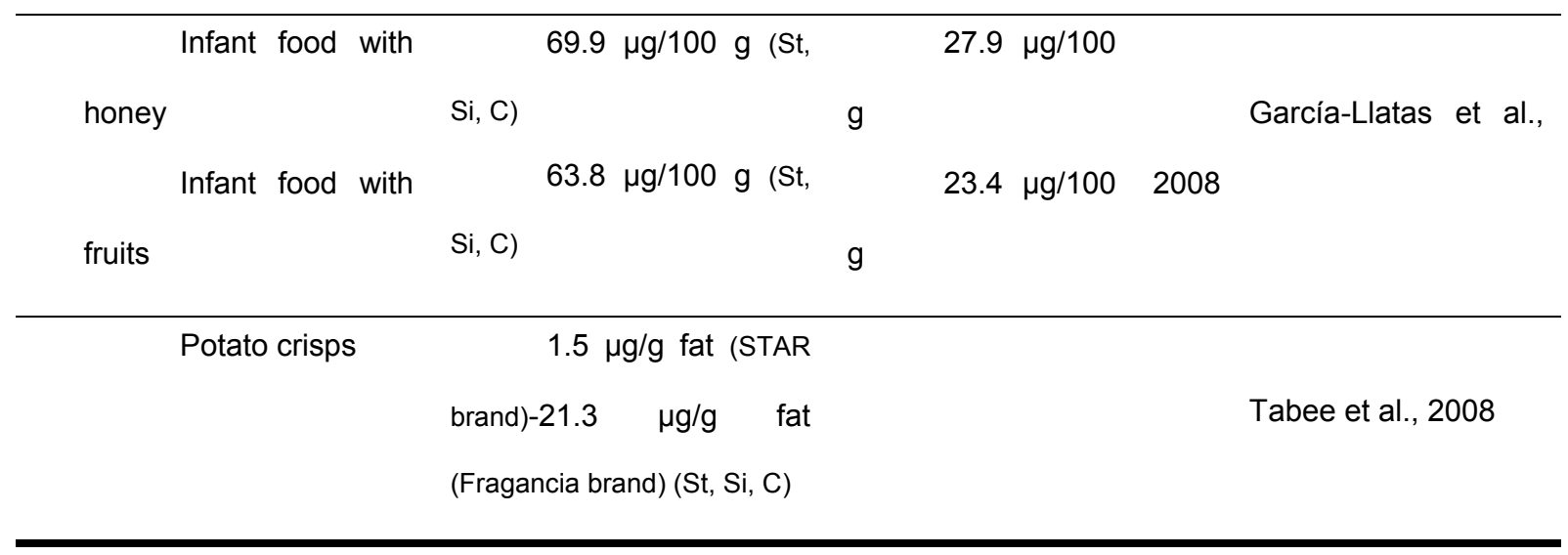

Enriched products

Phytosterol- $\quad 12.0 \mu \mathrm{g} / \mathrm{g}(\mathrm{St}, \mathrm{Si}, \mathrm{C})$

Johnsson and Dutta,

enriched spread

2006

$\begin{array}{llll}\text { Phytosterol- } & 46.5 \mu \mathrm{g} / \mathrm{g}(\mathrm{St}, \mathrm{Si}, \mathrm{C}) \quad \text { Conchillo et al., }\end{array}$




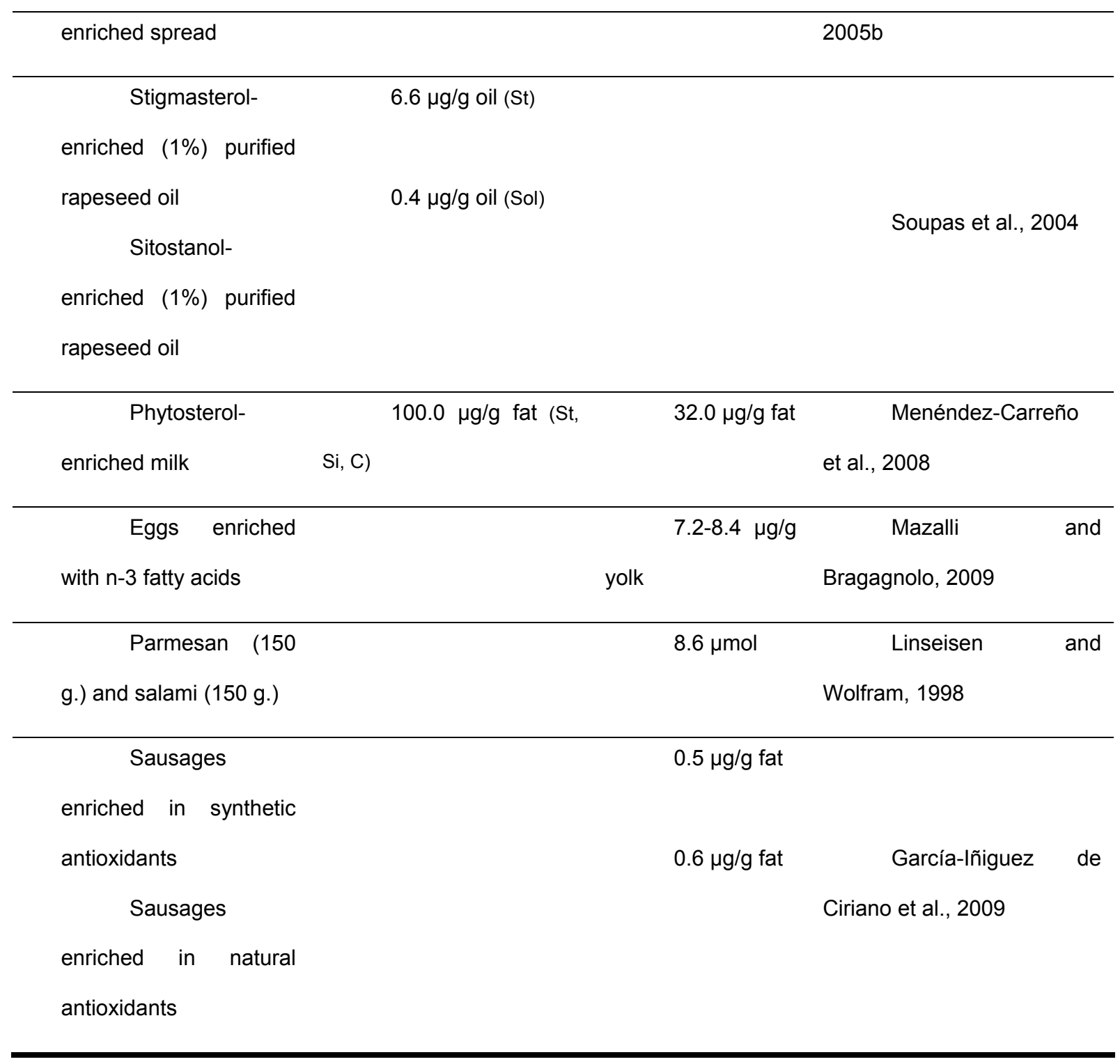




\section{References}

Abo, K., Mio, T., Sumino, K. 2000. Comparative analysis of plasma and erythrocyte 7ketocholesterol as a marker for oxidative stresss in patients with diabetes mellitus. Clin Biochem., 33(7), 541-547.

Adcox, C., Boyd, L., Oehrl, L., Allen, J., Fenner, G., 2001. Comparative effects of phytosterol oxides and cholesterol oxides in cultured macrophage-derived cell lines. $\mathrm{J}$ Agric Food Chem., 49(4), 2090-2095.

Andersson, S.W., Skinner, J., Ellegard, L., Welch, A.A., Bingham, S., Mulligan, A., Andersson, H., Khaw, K.T., 2004. Intake of dietary plant sterols is inversely related to serum cholesterol concentration in men and women in the EPIC Norfolk population: a cross-sectional study. Eur J Clin Nutr., 58, 1378-1385.

Alexandrov, P., Cui, J.G., Zhao, Y.H., Lukiw, W.J., 2005. 24S-hydroxycholesterol induces inflammatory gene expression in primary human neural cells. Neuroreport., 16(9), 909-913.

Ando, M., Tomoyori, H., Imaizumi, K., 2002. Dietary cholesterol-oxidation products accumulated in serum and liver in apolipoprotein E-deficient mice, but do not accelerate atherosclerosis. Br J Nutr., 88, 339-345.

Angulo, A. J., Romera, J. M., Ramirez, M., Gil, A., 1997. Determination of cholesterol oxides in dairy products. Effect of storage conditions. J Agric Food Chem., 45, 43184323.

Arca, M., Natoli, S., Micheletta, F., Riggi, S., Di Angelantonio, E., Montli, A., Antonini, MT., Antonini, R., Diczfalusy, U., luliano, L. 2007. Increased plasma levels of oxysterols, in vivo markers of oxidative stress, in patients with familial combined hyperlipidemia: Reduction during atorvastatin and fenofibrate therapy. Free Rad Biol Med., 42, 698-705.

Aringer, L., Eneroth, P., 1974. Formation and metabolism invitro of 5,6-epoxides of cholesterol and beta-sitosterol. J Lipid Res., 15, 389-398.

Aringer, L., Eneroth, P., Nordstrom, L., 1976. Side-chain hydroxylation of cholesterol, campesterol and beta-sitosterol in rat-liver mitochondria. J Lipid Res., 17, 263-272.

Azadmard-Damirchi, S. and Dutta, P.C., 2009. A single step solid-phase extraction method for complete separation of sterol oxidation products in food lipids. $J$ Chromatogr A., 1216(1), 36-42.

Berger, A., Jones, PJH., Abumweis, SS. 2004. Plant sterols: factors affecting their efficacy and safety as functional food ingredients. Lipids Health Dis., 3, 5.

Björkhem, I., Andersson, O., Diczfalusy, U., Sevastik, B., Xiu, RJ., Duan, C. 1994. Atherosclerosis and sterol 27-hydroxylase: evidence for a role of this enzyme in elimination of cholesterol from human macrophages. Proc Natl Acad Sci., 91, 85928596. 
Björkhem, I., Lütjohann, D., Diczfalusky, U., Stàhle, L., Ahlborg, G., Wahren, J. 1998. Cholesterol homeostasis in human brain: turnover of 24S-hydroxycholesterol and evidence for a cerebral origin of most of this oxysterol in the circulation. J Lipid Res., 39, 1594-1600.

Bonoli, M., Caboni, M.F., Rodriguez-Estrada, M.T., Lercker, G., 2008. Effect of processing technology on the quality and composition of lipids of precooked chicken patties. Int J Food Sci Technol., 43, 296-308.

Bortolomeazzi, R., Cordaro, F., Pizzale, L., Conte, L.S., 2003. Presence of phytosterol oxides in crude vegetable oils and their fate during refining. J Agric Food Chem., 51, 2394-2401.

Boselli, E., Caboni, M.F., Rodriguez-Estrada, M.T., Toschi, T.G., Daniel, M., Lercker, G., 2005. Photoxidation of cholesterol amd lipids of turkey meat during storage under commercial retail conditions. Food Chem., 91, 705-713.

Boselli, E., Rodriguez-Estrada, M.T., Fedrizzi, G., Caboni, M.F., 2009. Cholesterol photosensitised oxidation of beef meat under standard and modified atmosphere at retail conditions. Meat Science, 81, 224-229.

Bosner, MS., Lange, LG., Stenson, WF., Ostlund, Jr. RE. 1999. Percent cholesterol absorption in normal women and men quantified with dual stable isotopic tracers and negative ion mass spectrometry. J Lipid Res., 40, 302-308.

Breuer, O. and Björkhem, I., 1990. Simultaneous quantification of several cholesterol autoxidation and monohydroxylation products by isotope-dilution mass spectrometry. Steroids, 55(4), 185-192.

Brooks, C.J.W., Harland, W.A., Steel, G., 1966. Squalene, 26-hydroxycholesterol and 7-ketocholesterol in human atheromatous plaques. Biochim Biophys Acta., 125, 620622.

Brooks, C.J.W., McKenna, R.M., Cole, W.J., MacLachlan, J., Lawrie, T.D.V., 1983. Profile analysis of oxygenated sterols in plasma and serum. Biochem Soc Trans., 11, 700-701.

Brown, A.J. and Jessup, W., 2009. Oxysterols: Sources, cellular storage and metabolism, and new insights into their roles in cholesterol homeostasis. Mol Aspects Med., 30(3), 111-122.

Brufau, G., Canela, M.A., Rafecas, M., 2008. Phytosterols: physiologic and metabolic aspects related to cholesterol-lowering properties. Nutr Res.,28, 217-225.

Cercaci, L., Rodriguez-Estrada, M.T., Lercker, G. and Decker, E.A., 2007. Phytosterol oxidation in oil-in-water emulsions and bulk oil. Food Chem., 102(1), 161-167.

Chaurasia, N. and Nichtl, M. 1987. Sterols and steryl glucosides from Urtica dioica. J Nat Prod., 50, 881-885.

Chen, W., Chen, G., Head, DL., Mangelsdorf, DJ., Russell, DW. 2007. Enzymatic reduction of oxysterols impairs LXR sugnaling in cultured cells and the livers of mice. Cell Metab., 5, 73-79. 
Christiansion-Heika, I., Smeds, P., Granholm, N., Bergelin, E., Isomaa, B., 2007. Endocrine modulating actions of a phytosterol mixture in zebrafish (Danio rerio). Comp Biochem Physiol C Toxicol Pharmacol., 145, 518-527.

Conchillo, A., Ansorena, D., Astiasaran, I., 2005b. Intensity of lipid oxidation and formation of cholesterol oxidation products during frozen storage of raw and cooked chicken. J Sci Food Agric., 85, 141-146.

Conchillo, A., Cercaci, L., Ansorena, D., Rodriguez-Estrada, M.T., Lercker, G., Astiasaran, I., 2005a. Levels of phytosterol oxides in enriched and nonenriched spreads: application of a thin-layer chromatography-gas chromatography methodology. J Agr Food Chem., 53(20), 7844-7850.

D’Evoli, L., Huikko, L., Lampi, A.M., Lucarini, M., Lombardi-Boccia, G., Nicoli, S., Piironen, V., 2006. Influence of rosemary (Rosmarinus officinalis,L.) on plant sterol oxidation in extra virgin olive oil. Mol Nutr Food Res., 50, 818-823.

Derewiaka, D. and Obiedziński, M. 2009. Oxysterol content in selected meats and meat products. Acta Sci Pol Technol Aliment., 8 (3), 5-13.

Dutta, P.C., 1997. Studies on phytosterol oxides II: Content in some vegetable oils and in french fries prepared in these oils. J Am Oil Chem Soc., 74, 659-666.

Dzeletovic, S., Breuer, O., Lund, E., Diczfalusy, U., 1995. Determination of cholesterol oxidation products in human plasma by isotope dilution-mass spectrometry. Anal Biochem., 225(1), 73-80.

Echarte, M., Ansorena, D. and Astiasaran, I., 2003. Consequences of microwave heating and frying on the lipid fraction of chicken and beef patties. J Agric Food Chem., 51(20), 5941-5945.

Echarte, M., Zulet, M.A. and Astiasaran, I., 2001. Oxidation process affecting fatty acids and cholesterol in fried and roasted salmon. J Agric Food Chem., 49(11), 56625667.

Erridge, C., Webb, D.J., Spickett, C.M. 2007. 25-hydroxycholesterol, 7bhydroxycholesterol and 7-ketocholesterol upregulate interleukin-8 expression independently of toll-like receptor 1,2, 4 or 6 signalling in human macrophages. Free Radic Res., 41, 260-266.

Escurriol, V., Cofán, M., Moreno-Iribas, C., Larrañaga, N., Martínez, C., Navarro, C., Rodríguez, L., González, C.A., Corella, D., Ros, E., 2010. Phytosterol plasma concentrations and coronary heart disease in the prospective Spanish EPIC cohort. J Lipid Res., 51, 618-624.

Ferioli, F., Dutta, P.C., Caboni, M.F. 2010. Cholesterol and lipid oxidation in raw and pan-fried minced beef stored under aerobic packaging. J Sci Food Agric., 90, 10501055.

Fuda, H., Javitt, N.B., Mitamura, K., Ikegawa, S., Strott, C.A., 2007. Oxysterols are substrates for cholesterol sulfotransferase. J Lipid Res, 48, 1343-1352. 
Garcia-Cruset, S., Carpenter, KLH., Guardiola, F., Mitchinson, MJ. 1999. Oxysterols in cap and core of human advanced atherosclerotic lesions. Free Radic Res., 30(5), 341350.

Garcia-Cruset, S., Carpenter, KLH., Guardiola, F., Stein, BK., Mitchinson, MJ. 2001. Oxysterol profiles of human arteries, fatty streaks and advanced lesions. Free Radic Res., 35(1), 31-41.

García-Iñiguez de Ciriano, M., García-Herreros, C., Larequi, E., Valencia, I., Ansorena, D., Astiasarán, I. 2009. Use of natural antioxidants from lyophilized water extracts of Borago officinalis in dry fermented sausages enriched in $\omega-3$ PUFA. Meat Sci., 83, 271-277.

García-Llatas, G., Cercaci, L., Rodriguez-Estrada, M.T., Lagarda, M.J., Farré, R., Lercker, G., 2008. Sterol oxidation in rady-to-eat infant foods during storage. J Agric Food Chem., 56, 469-475.

Gill, S., Chow, R., Brown, A.J., 2008. Sterol regulators of cholesterol homeostasis and beyond: The oxysterol hypothesis revisited and revised. Prog Lipid Res., 47(6), 391404.

Grandgirard, A., Demaison-Meloche, J., Cordelet, C., Demaison, L., 2004d. Incorporation of oxyphytosterols in tissues of hamster. Reprod Nutr Dev., 44, 599-608.

Grandgirard, A., Martine, L., Demaison, L., Cordelet, C., Joffre, C., Berdeaux, O., Semon, E., 2004a. Oxyphytosterols are present in plasma of healthy human subjects. Brit J Nutr., 91, 101-106.

Grandgirard, A., Martine, L., Joffre, C., Juaneda, P. and Berdeaux, O., 2004c. Gas chromatographic separation and mass spectrometric identification of mixtures of oxyphytosterol and oxycholesterol derivatives: Application to a phytosterol-enriched food. J Chromatogr A., 1040(2), 239-250.

Grandgirard, A., Martine, L., Juaneda, P., Cordelet, C., 2004b. Sitostanetriol is not formed in vivo from sitosterol in the rat. Reprod Nutr Dev., 44, 609-616.

Grandgirard, A., Sergiel, J.P., Nour, M., Demaison-Meloche, J., Giniès, C., 1999. Lymphatic absorption of phytosterol oxides in rats. Lipids, 34 (6), 563-570.

Guardiola, F., 1994. Formation of oxysterols in egg powder during spray-drying and storage, Ph.D. Thesis, Universitat de Barcelona. Spain.

Guardiola, F., Codony, R., Addis, P.B., Rafecas, M., Boatella, J. 1996. Biological effects of oxysterols: Current status. Food Chem Toxicol., 34 (2), 193-211.

Guardiola, F., Dutta, PC., Codony, R., Savage, GP. 2002. Cholesterol and phytosterol oxidation products: analysis, occurrence, and biological effects. In 124-216; 241-277; 319-334.

Heinemann, T., Axtmann, G., Vonbergmann, K. 1993. Comparison of intestinalabsorption of cholesterol with different plant sterols in man. Eur J Clin Invest., 23 (12), 827-831. 
Higashi, Y., Fuda, H., Yanai, H., Young, L., Fukushige, T., Kanzaki, T., Strott, C.A., 2004. Expression of cholesterol sulfotransfera (SULT2B1b) in human skin and primary cultures of human epidermal keratinocytes. J Invest Dermatol., 122 (5), 1207-1213.

Hovenkamp, E., Demonty, I., Plat, J., Lütjohann, D., Mensink, R.P., Trautwein, E.A., 2008. Biological effects of oxidized phytosterols: A review of the current knowledge. Prog Lipid Res., 47(1), 37-49.

Ikeda, I., Konno, R., Shimizu, T., Ide, T., Takahashi, N., Kawada, T., 2006. Campest-5en-3-one, an oxidized derivative of campesterol, activates PPARalpha, promotes energy consumption and reduces visceral fat deposition in rats. Biochim Biophys Acta., $1760,800-807$.

Jacobson, M.S., 1987. Cholesterol oxides in Indian ghee: possible cause of unexplained high risk of atherosclerosis in Indian immigrant populations. Lancet, 11, 656-658.

Jessup, W., Wilson, P., Gaus, K., Kritharides, L., 2002. Oxidized lipoproteins and macrophages. Vascul Pharmacol., 38, 239-248.

Johnsson, L. and Dutta, P.C., 2006. Determination of phytosterol oxides in some food products by using an optimized transesterification method. Food Chem., 97(4), 606613.

Katan, MB., Grundy, SM., Jones, P., Law, M., Miettinen, T., Paoletti, R. 2003. Efficacy and safety of plant stanols and sterols in the management of blood cholesterol levels. Mayo Clin Proc., 78, 965-978.

Kemmo, S., Soupas, L., Lampi, A.M., Piironen, V., 2005. Formation and decomposition of stigmasterol hydroperoxides and secondary oxidation products during thermooxidation. Eur J Lipid Sci Technol., 107, 805-814.

Kimura, Y., Yasukawa, K., Takido, M., Akihisa, T., Tamura, T., 1995. Inhibitory effect of some oxygenated stigmastane-type sterols on 12-O-tetradecanoylphorbol-13-acetateinduced inflammation in mice. Boil Pharm Bull., 18, 1617-1619.

Kmiecik, D., Korczak, J., Rudzińska, M., Michalowska, A.G., Hęś, M., 2009. Stabilization of phytosterols in rapeseed oil by natural antioxidants during heating. Eur J Lipid Sci Technol., 111, 1124-1132.

Kuhlmann, K., Lindtner, O., Bauch, A., Ritter, G., Woemer, B., Niemann, B., 2005. Simulation of prospective phytosterol intake in Germany by novel functional foods. Brit J Nutr., 93, 377-385.

Lampi, AM., Juntunen, L., Toivo, J., Piironen, V. 2002. Determination of thermooxidation products of plant sterols. J Chromatogr. B, 777, 83-92.

Lange, Y., Ory, DS., Ye, J., Lanier, MH., Hsu, F-F., Steck, TL. 2008. Effectors of rapid homeostatic responses of endoplasmic reticulum cholesterol and HMG-CoA reductase. J Biol Chem.,283,1445-1455. 
Larsson, DA., Baird, S., Nyhalah, JD., Yuan, XM., Li, W. 2006. Oxysterols mixtures, in atheroma-relevant proportions, display synergistic and proapoptotic effects. Free Rad Biol Med., 41, 902-910.

Larsson, H., Bottiger, Y., luliano, L., Diczfalusky, U., 2007. In vivo interconversion of $7 \beta$-hydroxycholesterol and 7-ketocholesterol, potential surrogate markers for oxidative stress. Free Radic Biol Med, 43, 695-701.

Lemaire, S., Lizard, G., Monier, S., Miguet, C., Gueldry, S., Volot, F., Gambert, P., Néel, D., 1998. Different patterns of IL-1b secretion, adhesion molecule expression and apoptosis induction in human endothelial cells treated with 7a-, 7b-hydroxycholesterol, or 7-ketocholesterol. FEBS Lett., 440, 434-439.

Lemaire-Ewing, S., Berthier, A., Royer, M.C., Logette, E., Corcos, L., Bouchot, A., Monier, S., Prunet, C., Raveneau, M., Rébé, C., Desrumaux, C., Lizard, G., Néel, D. 2009. 7b-hydroxycholesterol and 25-hydroxycholesterol-induced interleukin-8 secretion involves a calcium-dependent activation of c-fos via the ERK1/2 signaling pathway in THP-1 cells: oxysterols-induced IL-8 secretion is calcium-dependent. Cell Biol Toxicol., $25,127-139$.

Lemaire-Ewing, S., Prunet, C., Montange, T., Vejux, A., Berthier, A., Bessède, G., Corcos, L., Gambert, P., Néel, D., Lizard, G. 2005. Comparison of the cytotoxic, prooxidant and pro-inflammatory characteristics of different oxysterols. Cell Biol Toxicol., 21, 97-114.

Leonarduzzi, G., Sevanian, A., Sottero ,B., Arkan, M.C., Biasi, F., Chiarpotto, E., Basaga, H., Poli, G. 2001. Up-regulation of the fibrogenic cytokine TGF-beta 1 by oxysterols: a mechanistic link between cholesterol and atherosclerosis. FASEB, 15, 1619-1621.

Leonarduzzi, G., Gamba, P., Sottero, B., Kadl, A., Robbesyn, F., Calogero, R.A., Biasi, F., Chiarpotto, E., Leitinger, N., Sevanian, A., Poli, G. 2005. Oxysterol-induced upregulation of MCP-1 expression and synthesis in macrophage cells. Free Radic Biol Med., 39, 1152-1161.

Leonarduzzi, G., Sottero, B., Poli, G., 2002. Oxidized products of cholesterol: dietary and metabolic origin, and proatherosclerotic effects (review). J Nutr Biochem., 13(12), 700-710.

Lercker, G. and Rodriguez-Estrada, M.T., 2000. Cholesterol Oxidation: Presence of 7ketocholesterol in Different Food Products. J Food Comp Anal., 13(4), 625-631.

Linseisen, J. and Wolfram, G., 1998. Absorption of cholesterol oxidation products from ordinary foodstuff in humans. Ann Nutr Metab., 42, 221-230.

Lund, E., Andersson, O., Zhang, J., Babiker, A., Ahlborg, G., Diczfalusy, U. 1996. Importance of a novel oxidative mechanism for elimination of intracellular cholesterol in humans. Arteriosclerosis, thrombosis, and vascular biology., 16, 208-212.

Lund, EG., Kerr, TA., Sakai, J., Li, WP., Russell, DW. 1998. CDNA cloning of mouse and human cholesterol 25-hydroxylases, polytopic membrane proteins that synthesize a potent oxysterol regulator of lipid metabolism. J Biol Chem., 273, 34316-34327. 
Lütjohann, D., Björkhem, I., Beil, UF., von Bergmann, K. 1995. Sterol absorption and sterol balance in phytosterolemia evaluated by deuterium-labeled sterols: effect of sitostanol treatment. J Lipid Res., 36, 1763-1773.

Lyous, M.A., and Brown, A.J., 2001. Metabolism of an oxysterol, 7-ketocholesterol, by sterol 27-hydroxylase in HepG2 cells. Lipids, 36, 701-711.

Maguire, L., Konoplyannikov, M., Ford, A., Maguire, A.R., O’Brien, N.M., 2003. Comparison of the cytotoxic effects of $\beta$-sitosterol oxides and a cholesterol oxide, $7 \beta$ hidroxycholesterol, in cultured mammalian cells. Br J Nutr, 90, 767-775.

Mazalli, M.R. and Bragagnolo, N. 2009. Increase of cholesterol oxidation and decrease of PUFA as a result of thermal processing and storage in eggs enriched with n-3 fatty acids. J Agric Food Chem., 57, 5028-5034.

McCarthy, FO., Chopra, J., Ford, A., Hogan, SA., Kerry, JP., O’Brien, NM., Ryan, E., Maguire, AR. 2005. Synthesis, isolation and characterisation of $\beta$-sitosterol and $\beta$ sitosterol oxide derivatives. Org Biomol Chem., 3, 3059-3065.

Menéndez-Carreño, M. 2009. Sterol oxidation products in serum and enriched food: analysis, formation and relation to oxidative stress. Ph.D. Thesis, Universidad de Navarra, Spain.

Menéndez-Carreño, M., Ansorena, D. and Astiasarán, I., 2008b. Stability of sterols in phytosterol-enriched milk under different heating conditions. J Agric Food Chem., 56(21), 9997-10002.

Menéndez-Carreño, M., Ansorena, D., Astiasarán, I., Piironen, V., Lampi, A.M. 2010. Determination of non-polar and mid-polar monomeric oxidation products of stigmasterol during thermo-oxidation. Food Chem., 122, 277-284.

Menéndez-Carreño, M., García-Herreros, C., Astiasarán, I., Ansorena, D. 2008a. Validation of a gas chromatography-mass spectrometry method for the analysis of sterol oxidation products in serum. J Chromatogr. B. Analyt Technol Biomed Life Sci., 864(1-2), 61-68.

Meyer, W., Jungnickel, H., Janijke, M., Dettner, K., Spitellier, G., 1998. On the cytotoxicity of oxidised phytosterols isolated from photoautotrophic cell cultures of chenopodium rubrum tested on meal-worms tenebrio molitor. Phytochemistry, 47, 789797.

Meynier, A., Andre, A., Lherminier, J., Grandgirard, A., Demaison, L., 2005. Dietary oxysterols induce in vivo toxicity of coronary endothelial and smooth muscle cells. Eur J Nutr., 44, 393-405.

Miettinen, T.A., Puska, P., Gylling, H., Vanhanen, H., Vartiainen, E. 1995. Reduction of serum cholesterol with sitostanol-ester margarine in a mildly hypercholesterolemic population. New Engl J Med., 333, 1308-1312.

Myoishi, M., Hao, H., Minamino, T., Watanabe, K., Nishihira, K., Hatakeyama, K., Asada, Y., Okada, K.-I., Ishibashi-Veda, H., Gabbiani, G., Bochaton-Piallat, M.-L., Mochizuki, N., Kitakaze, M. 2007. Increased endoplasmic reticulum stress in atherosclerotic plaques associated with acute coronary syndrome. Circulation, 116, 1226-1233. 
Novelli, E., Zanardi, E., Ghiretti, G.P., Campanini, G., Dazzi, G., Madarena, G., Chizzolini, R., 1998. Lipid and cholesterol oxidation in frozen stored pork, salame milano and mortadella. Meat Sci., 48, 29-40.

O'Callaghan, Y.C., Woods, J.A., O’Brien, N.M., 2001. Comparative study of the cytotoxicity and apoptosis-inducing potential of commonly occurring oxysterols. Cell Biol Toxicol., 17, 127-137.

Osada, K., Hoshina, S., Nakamura, S., Sugano, M., 2000. Cholesterol oxidation in meat products and its regulation by supplementation of sodium nitrite and apple polyphenol before processing. J Agric Food Chem., 48, 3823-3829.

Osada, K., Sasaki, E., Sugano, M., 1994. Lymphatic absorption of oxidized cholesterol in rats. Lipids, 29(8), 555-559.

Ostlund, Jr.RE, McGill, JB., Zeng, CM., Covey, DF., Stearns, J., Stenson, WF. 2002. Gastrointestinal absorption and plasma kinetics of soy Delta(5)-phytosterols and phytosterols in humans. Am J Physiol Endocrinol Metab, 282, 911-916.

Pelletier, X., Belbraouet, S., Mirabel, D., Mordret, F., Perrin, J.L., Pages, X., Debry, G. 1995. A diet moderately enriched in phytosterols lowers plasma cholesterol concentrations in normocholesterolemic humans. Ann Nutr Metab., 39 (5), 291-295.

Peng. S.K., Morin, R.J., Tham, P., Taylor, C.B., 1985. Effects of oxygenated derivatives of cholesterol on cholesterol uptake by cultured aortic smooth muscle cells. Artery, 18, 87-98.

Peterson, D.W. 1951. Effects of soybean sterols in the diet on plasma and liver cholesterol in chicks. Proc Soc Exp Biol Med., 78 (1), 143-147.

Pie, J.E., Spahis, K., Seillan, C., 1990. Evaluation of oxidative degradation of cholesterol in food and food ingredients : Identification and quantification of cholesterol oxides. J Agric Food Chem., 38, 973-979.

Pie, J.E., Spahis, K., Seillan, C., 1991. Cholesterol oxidation in meat products during cooking and frozen storage. J Agric Food Chem., 39, 250- 254.

Pignoli, G., Rodriguez-Estrada, MT., Mandrioli, M., Barbanti, L., Rizzi, L., Lercker, G. 2009. Effects of different rearing and feeding systems on lipid oxidation and antioxidant capacity of freeze-dried egg yolks. J Agric Food Chem., 57 (24), 11517-11527.

Plat, J., Brzezinka, H., Lütjohann, D., Mensink, R.P., Bergmann, K., 2001. Oxidized plant sterols in human serum and lipid infusions as measured by combined gas-liquid chromatography-mass spectrometry. J Lipid Res., 42, 2030-2038.

Plat, J. and Mensink, RP. 2002. Increased intestinal ABCA1 expression contributes to the decrease in cholesterol absorption after plant stanol consumption. FASEB J., 16, 1248-1253.

Plat, J., Nichols, J.A., Mensink, R.P., 2005. Plant sterols and stanols: effects on mixed micellar composition and LXR (target gene) activation. J Lipid Res., 46, 2468-2476. 
Poli, G., Leonarduzzi, G., Biasi, F., Chiarpotto, E., 2004. Oxidative stress and cell signalling. Curr Med Chem., 11, 1163-1182.

Poli, G., Sottero, B., Gargiulo, S., Leonarduzzi, G., 2009. Cholesterol oxidation products in the vascular remodeling due to atherosclerosis. Mol Aspects Med., 30(3), 180-189.

Prunet, C., Lemaire-Ewing, S., Menetrier, F., Néel, D., Lizard, G., 2005. Activation of caspase-3-dependent and -independent pathways during 7-ketocholesterol- and 7 beta-hydroxycholesterol-induced cell death: A morphological and biochemical study. J. Biochem Mol Toxicol., 19(5), 311-326.

Prunet, C., Montange, T., Véjux, A., Laubriet, A., Rohmer, J.F., Riedinger, J.M., Athias, A., Lemaire-Ewing, S., Néel, D., Petit, J.M., Steinmetz, E., Brenot, R., Gambert, P., Lizard, G. 2006. Multiplexed flow cytometric analyses of pro- and anti-inflammatory cytokines in the culture media of oxysterol-treated human monocytic cells and in the sera of atherosclerotic patients. Cytometry A, 69, 359-373.

Raaphorst, G.P., Azzam, E.I., Langlois, R., Van Lier, J.E., 1987. Effect of cholesterol alpha and beta epoxides on cell killing and transformation. Biochem Pharmacol., 36, 2369-2372.

Romeo, G., Frangioni, J.V., Kazlauskas, A. 2004. Profilin acts downstream of LDL to mediate diabetic endothelial cell dysfunction. FASEB J., 18, 725-727.

Roussi, S., Gossé, F., Aoudé-Werner, D., Zhang, X., Geoffroy, P., Miesch, M., Marchioni, E., Raul, F., 2006. Perturbation of polyamine metabolism and its relation to cell death in human colon cancer cells treated by $7 \beta$-hydroxycholesterol and $7 \beta$ hydroxysitosterol. Int J Oncol., 29, 1549-1554.

Roussi, S., Gossé, F., Aoudé-Werner, D., Zhang, X., Marchioni, E., Geoffroy, P., Miesch, M., Raul, F., 2007. Mitochondrial perturbation, oxidative stress and lysosomal destabilization are involved in $7 \beta$-hydroxysitosterol and $7 \beta$-hydroxycholesterol triggered apoptosis in human colon cancer cells. Apoptosis, 12(1), 87-96.

Roussi, S., Winter, A., Gosse, F., Werner, D., Zhang, X., Marchioni, E., Geoffroy, P., Miesch, M., Raul, F., 2005. Different apoptotic mechanisms are involved in the antiproliferative effects of $7 \beta$-hydroxysitosterol and $7 \beta$-hydroxycholesterol in human colon cancer cells. Cell Death Differ., 12(2), 128-135.

Rozner, S. and Garti, N. 2006. The activity and absorption relationship of cholesterol and phytosterols. Colloids Surfaces A: Physicochem Eng Aspects., 283, 435-456.

Russell, DW. 2000. Oxysterol biosynthetic enzymes. Biochim Biophys Acta, 1529, 126135.

Ryan, E., Chopra, J., McCarthy, F.O., Maguire, A.R., O’Brien, N.M., 2005. Qualitative and quantitative comparison of the cytotoxic and apoptotic potential of phytosterol oxidation products with their corresponding cholesterol oxidation products. $\mathrm{Br} \mathrm{J}$ Nutr., 94, 443-451.

Ryan, E., McCarthy, F.O., Maguire, A.R., O'Brien, N.M., 2009. Phytosterol Oxidation Products: Their Formation, Occurrence, and Biological Effects. Food Rev Int., 25(2), 157-174. 
Rydberg, E.K., Salomonsson, L., Hulten, L.M., Noren, K., Bondjers, G., Wiklund, O., Bjornheden, T., Ohlsson, B.G. 2003. Hypoxia increases 25-hydroxycholesterol-induced interleukin-8 protein secretion in human macrophages. Atherosclerosis, 170, 245-252.

Saldanha, T., Benassi, M.T., Bragagnolo, N. 2008. Fatty acid contents evolution and cholesterol oxides formation in Brazilian sardines (Sardinella brasiliensis) as a result of frozen storage followed by grilling. Food Sci Technol., 41, 1301-1309.

Salen, G., Shefer, S., Nguyen, L., Ness, GC., Tint, GS., Shore, V. 1992. Sitosterolemia. J Lipid Res, 33, 945-955.

Sánchez-Molinero, F., García-Regueiro, J.A., Arnau, J. 2010. Processing of dry-cured ham in a reduced-oxygen atmosphere: Effects on physicochemical and microbiological parameters and mite growth. Meat Sci., 84, 400-408.

Sander, B.D., Addis, P.B., Park, S.W., Smith, D.E., 1989. Quantification of cholesterol oxidation products in a variety of foods. J Food Prot., 52, 109-114.

Sarantinos, J., O’Dea, K., Sinclair, A.J., 1993. Cholesterol oxides in Australian foods. Identification and quantification. Food Aust., 45, 485-490.

Schroeder, G., Rohmer, M., Beck, JP., Anton, R. 1980. 7-oxo-, 7[alpha]-hydroxy- and 7[beta]-hydroxysterols from Euphorbia fischeriana. Phytochemistry, 19, 2213-2215.

Schroepfer, G.J., Jr., 2000. Oxysterols: Modulators of Cholesterol Metabolism and Other Processes. Physiol Rev., 80(1), 361-554.

Schweizer, RAS., Zurcher, M., Balazs, Z., Dick, B., Odermatt, A. 2004. Rapid hepatic metabolism of the rat, human and hamster enzyme. J Biol Chem., 279, 18415-18424.

Seet, RCS., Lee, C-Y.J., Lim, ECH., Tan, JJH., Quek, AML., Chong, W-L., Looi, W-F., Huang, S-H., Wang, H., Chan, Y-H., Halliwell, B. 2010. Oxidative damage in Parkinson disease: measurement using accurate biomarkers. Free Radic Biol Med., 48 (4): 560566.

Shozen, K., Ohshima, T., Ushio, H., Takiguchi, A., Koizumi, C., 1997. Effects of antioxidants and packing on cholesterol oxidation in processed anchovy during storage. Lebensm-Wiss Technol., 30, 2-8.

Simons, K. and Ikonen, E. 2000. How cells handle cholesterol. Science, 290, 17211726.

Smith, LL. 1981. Cholesterol autoxidation. New York: Plenum Press.

Smith, LL. 1996. Reviews of progress in sterol oxidation: 1987-1995. Lipids, 31, 453487.

Soto-Rodriguez, I., Campillo-Velazquez, PJ., Alexander-Aguilera, A., RodriguezEstrada, MT., Lercker, G., García, HS. 2009. Biochemical and histopathological effects of dietary oxidized cholesterol in rats. J Appl Toxicol., 29 (8), 715-723. 
Soto-Rodríguez, I., Campillo-Velázquez, P.J., Ortega-Martínez, J., Rodriguez-Estrada, M.T., Lercker, G., Garcia, H.S., 2008. Cholesterol oxidation in traditional Mexican dried and deep-fried food products. J Food Comp Anal., 21, 489-495.

Sottero, B., Gamba, P., Gargiulo, S., Leonarduzzi, G., Poli, G., 2009. Cholesterol oxidation products and disease: an emerging topic of interest in medicinal chemistry. Curr Med Chem., 16(6), 685-705.

Soupas, L., Huikko, L., Lampi, A.M., Piironen, V., 2005. Esterification affects phytosterol oxidation. Eur J Lipid Sci Technol., 107, 107-118.

Soupas, L., Juntuned, L., Lampi, A.M., Piironen, V., 2004. Effects of sterol structure, temperature, and lipid medium on phytosterol oxidation. J Agric Food Chem., 52, 64856491.

Staprans, I., Pan, X.M., Rapp, J.H., Feingold, K.R., 2003. Oxidized cholesterol in the diet is a source of oxidized lipoproteins in human serum. J Lipid Res., 44, 705-715.

Staprans, I., Pan, X.M., Rapp, J.H., Feingold, K.R., 2005. The role of dietary oxidized cholesterol and fatty acids in the development of atherosclerosis. Mol Nutr Food Res., 49, 1075-1082.

Staprans, I., Pan, X.M., Rapp, J.H., Grunfeld, C., Feingold, K.R., 2000. Oxidized cholesterol in the diet accelerates the development of atherosclerosis in LDL receptorand apolipoprotein E- deficient mice. Aterioscler Thromb Vasc Biol., 20, 708-714.

Steinberg, D., 2002. Atherogenesis in perspective: hypercholesterolemia and inflammation as partners in crime. Nat Med., 8(11), 1211-1217.

Stocker, R., Keaney, JF. Jr. 2004. Role of oxidative modifications in atherosclerosis. Physiol Rev., 84, 1381-1478.

Suzuki, K., Tanaka, M., Konno, R., Kaneko, Y., 2002. Effects of 5-campestenone (24methylcholest-5-en-3-one) on the type 2 diabetes mellitus model animal C57BL/KsJ$\mathrm{db} / \mathrm{db}$ mice. Horm Metab Res., 34, 121-126.

Szuchman, A., Aviram, M., Musa, R., Khatib, S., Vaya, J. 2008. Characterization of oxidative stress in blood from diabetic vs. hypercholesterolaemic patients, using a novel synthesized marker. Biomarkers, 13(1), 119-131.

Tabee, E., Jägerstad, M., Dutta, P.C., 2008. Lipids and phytosterol oxidation products in commercial potato crisps commonly consumed in Sweden. Eur. Food Res. Technol., $227,745-755$.

Tai, CY., Chen, YC., Chen, BM. 1999. Analysis, formation and inhibition of cholesterol oxidation products in foods: an overview (part I). J Food Drug Anal., 7, 243-257.

Talon, R., Leroy, S., Lebert. I., Giammarinaro, P., Chacornac, J.P., Latorre-Moratalla, M., Vidal-Carou, C., Zanardi, E., Conter, M., Lebecque, A. 2008. Safety improvement and preservation of typical sensory qualities of traditional dry fermented sausages using autochthonous starter cultures. Int J Food Microbiol., 126, 227-234. 
Tomoyori, H., Kawata, Y., Higuchi, T., Ichi, I., Sato, H., Sato, M., Ikeda, I., Imaizumi, K., 2004. Phytosterol oxidation products are absorbed in the intestinal lymphatics in rats but do not accelerate atherosclerosis in apolipoprotein-E deficient mice. J Nutr., 134, 1690-1696.

Tonello, A., 2006. Letter to the editor: Serum phytosterols not only from dietary intake. Brit J Nutr., 96, 791-792.

Ubhayasekera, SJKA., Tres, A., Codony, R., Dutta, PC. 2010a. Effects of different levels of trans fatty acids and oxidised lipids in diet on cholesterol and cholesterol oxidation products formation in rabbit. Food Chem., 121 (4), 1198-1202.

Ubhayasekera, SJKA., Tres, A., Codony, R., Dutta, PC. 2010b. Effect of feed fat byproducts with trans fatty acids and heated oil on cholesterol and oxycholesterols in chicken. J Am Oil Chem Soc., 87 (2), 173-184.

Valencia, I., O'Grady, M.N., Ansorena, D., Astiasarán, I., Kerry, J.P., 2008. Enhancement of the nutritional status and quality of fresh pork sausages following the addition of linseed oil, fish oil and natural antioxidants. Meat Sci., 80(4), 1046-1054.

Van-Reyk, D.M., Brown, A.J., Hult'en, L.M., Dean, R.T., Jesup, W., 2006. Oxysterols in biological systems: sources, metabolism and pathophysiological relevance. Redox Rep., 11, 255-262.

Vanhanen, H.T., Blomqvist, S., Ehnholm, C., Hyvonen, M., Jauhiainen, M., Torstila, I., Miettinen, T.A. 1993. Serum-cholesterol, cholesterol precursors, and plant sterols in hypercholesterolemic subjects with different ApoE phenotypes during dietary sitostanol ester treatment. J Lipid Res., 34 (9), 1535-1544.

Vejux, A., Lizard, G. 2009. Cytotoxic effects of oxysterols associated with human diseases: Induction of cell death (apoptosis and/or oncosis), oxidative and inflammatory activities, and phospholipidosis. Mol Aspects Med., 30(3), 153-170.

Vejux, A., Guyot, S., Montange, T., Riedinger, J.M., Kahn, E., Lizard, G. 2009. Phospholipidosis and down-regulation of the PI3-K/PDK-1/Akt signalling pathway are vitamin $\mathrm{E}$ inhibitable events associated with 7-ketocholesterol-induced apoptosis. $\mathrm{J}$ Nutr Biochem., 20(1), 45-61.

Verardo, V., Pasini, F., lafelice, G., Messia, M.C., Marconi, E., Caboni, M.F. 2010. Influence of storage conditions on cholesterol oxidation in dried egg pasta. J Agric Food Chem., 58, 3586-3590.

Vine, D.F., Mamo, J.C.L., Beilin, L.J., Mori, T.A., Croft, K.D., 1998. Dietary oxysterols are incorporated in plasma triglyceride-rich lipoproteins, increase their susceptibility to oxidation and increase aortic cholesterol concentration of rabbits. J Lipid Res., 39, 1995-2004.

Xu, G., Guan, L., Sun, J., Chen, Z.Y., 2009. Oxidation of cholesterol and $\beta$-sitosterol and prevention by natural antioxidants. J Agric Food Chem., 57 (19), 9284-9292.

Yanai, H., Javitt, N.B., Higashi, Y., Fuda, H., Strott, C.A., 2004. Expression of cholesterol sulfotransferase (SULT2B1b) in human platelets. Circulation, 109, 92-96. 
Yen. T.Y., Stephen Inbaraj, B., Chien, J.T., Chen, B.H. 2010. Gas chromatographymass spectrometry determination of conjugated linoleic acids and cholesterol oxides and their stability in a model system. Anal Biochem., 400, 130-138.

Zanardi, E., Battaglia, A., Ghidini, S., Conter, M., Badiani, A., lanieri, A. 2009. Lipid oxidation of irradiated pork products. Food Sci Technol., 42, 1301-1307.

Zanardi, E., Dorigoni, V., Badiani, A. and Chizzolini, R., 2002. Lipid and colour stability of Milano-type sausages: effect of packing conditions. Meat Sci., 61(1), 7-14.

Zhang, X., Julien-David, D., Miesch, M., Raul, F., Geoffroy, P., Aoude-Werner, D., Ennahar, S. and Marchioni, E., 2006. Quantitative analysis of $\beta$-sitosterol oxides induced in vegetable oils by natural sunlight, artificially generated light, and irradiation. J Agric Food Chem., 54(15), 5410-5415.

Zhou, Q., Wasowicz, E., Handler, B., Fleischer, L., Kummerow, FA. 2000. An excess concentration of oxysterols in the plasma is cytotoxic to cultures endothelial cells. Atherosclerosis, 149, 191-197.

Zubillaga, M.P., and Maerker, G., 1991. Quantification of three cholesterol oxidation products in raw meat and chicken. J Food Sci., 56, 1194-1196.

Zunin, P., Boggia, R., Evangelisti, F., 2001. Identification and quantification of cholesterol oxidation products in canned tuna. J Am Oil Chem Soc., 78, 1037-1040. 